\title{
Silicon-induced thermotolerance in Solanum lycopersicum L. via activation of antioxidant system, heat shock proteins, and endogenous phytohormones
}

Adil Khan', Abdul Latif Khan ${ }^{1 *}$ (D, Muhammad Imran², Sajjad Asaf', Yoon-Ha Kim², Saqib Bilal', Muhammad Numan ${ }^{1}$, Ahmed Al-Harrasi ${ }^{1 *}$, Ahmed Al-Rawahi ${ }^{1}$ and In-Jung Lee ${ }^{2}$

\begin{abstract}
Background: Abiotic stresses (e.g., heat or limited water and nutrient availability) limit crop production worldwide. With the progression of climate change, the severity and variation of these stresses are expected to increase. Exogenous silicon (Si) has shown beneficial effects on plant growth; however, its role in combating the negative effects of heat stress and their underlying molecular dynamics are not fully understood.

Results: Exogenous Si significantly mitigated the adverse impact of heat stress by improving tomato plant biomass, photosynthetic pigments, and relative water content. Si induced stress tolerance by decreasing the concentrations of superoxide anions and malondialdehyde, as well as mitigating oxidative stress by increasing the gene expression for antioxidant enzymes (peroxidases, catalases, ascorbate peroxidases, superoxide dismutases, and glutathione reductases) under stress conditions. This was attributed to increased Si uptake in the shoots via the upregulation of low silicon (SILsi1 and S/Lsi2) gene expression under heat stress. Interestingly, Si stimulated the expression and transcript accumulation of heat shock proteins by upregulating heat transcription factors (Hsfs) such as SIHsfAla-b, SIHSFA2-A3, and SIHsfA7 in tomato plants under heat stress. On the other hand, defense and stress signaling-related endogenous phytohormones (salicylic acid [SA]/abscisic acid [ABA]) exhibited a decrease in their concentration and biosynthesis following Si application. Additionally, the mRNA and gene expression levels for SA (SIR1b1, SIPR-P2, SIICS, and SIPAL) and ABA (SINCEDI) were downregulated after exposure to stress conditions.

Conclusion: $\mathrm{Si}$ treatment resulted in greater tolerance to abiotic stress conditions, exhibiting higher plant growth dynamics and molecular physiology by regulating the antioxidant defense system, SA/ABA signaling, and Hsfs during heat stress.
\end{abstract}

Keywords: Solanum lycopersicum L., Silicon, Heat stress, Antioxidant, Heat shock protein

\footnotetext{
* Correspondence: latifepm78@yahoo.co.uk; aharrasi@unizwa.edu.om

'Natural \& Medical Sciences Research Center, University of Nizwa, Nizwa 616,

Oman

Full list of author information is available at the end of the article
}

(c) The Author(s). 2020 Open Access This article is licensed under a Creative Commons Attribution 4.0 International License, which permits use, sharing, adaptation, distribution and reproduction in any medium or format, as long as you give appropriate credit to the original author(s) and the source, provide a link to the Creative Commons licence, and indicate if changes were made. The images or other third party material in this article are included in the article's Creative Commons licence, unless indicated otherwise in a credit line to the material. If material is not included in the article's Creative Commons licence and your intended use is not permitted by statutory regulation or exceeds the permitted use, you will need to obtain permission directly from the copyright holder. To view a copy of this licence, visit http://creativecommons.org/licenses/by/4.0/ The Creative Commons Public Domain Dedication waiver (http://creativecommons.org/publicdomain/zero/1.0/) applies to the data made available in this article, unless otherwise stated in a credit line to the data. 


\section{Background}

Abiotic stress (heat, drought, salinity, and heavy metals) can reduce crop productivity by up to $51-82 \%$ [1]. Notably, heat stress is recognized as a major adverse condition affecting yield loss, which is particularly relevant given the current context of global warming and climate change, with temperatures expected to increase by $2{ }^{\circ} \mathrm{C}$ [2]. It is predicted that a global temperature increase of $3-4{ }^{\circ} \mathrm{C}$ would cause a $15-35 \%$ reduction in crop productivity [3]. This scenario will subject crops to a larger range of environmental stressors that could occur simultaneously, leading to severe adverse impacts on crop productivity and future global food security [4]. Physiologically, plants have a well-developed heat stress response (HSR), involving numerous signaling pathways in response to heat stress to minimize or prevent damage during short- and long-term heat exposure [5]. When plants experience heat stress, they undergo morphophysiological, biochemical, phytohormonal, and transcriptional changes such as osmotic imbalance, enzyme inactivation, reactive oxygen species (ROS) overproduction, and organelle damage, which can lead to cell death $[2,6,7]$. With the predicted increase in the frequency and intensity of heat stress, the rate osmotic potential is significantly hindered by the creation of a cell water potential imbalance, causing tissue damages and influencing essential biochemical pathways. To survive under varying temperature conditions, plants have evolved multiple internal tolerance strategies, such as the secretion of heat shock proteins (HSPs), changes in phytohormone levels, and the scavenging of ROS by different oxidation-reduction enzymes [5]. Furthermore, as molecular chaperones, HSPs play a crucial role in facilitating native protein folding and preventing the irreversible aggregation of denatured proteins. In peanuts, the accumulation of small HSPs was shown to improve heat stress resistance [8]. Studies have also shown that elevated levels of antioxidants are associated with increased thermotolerance [2, 9]. Over-emphasis on individual phytohormones or the interplay of phytohormonal regulation, such as abscisic acid (ABA), salicylic acid (SA), and jasmonic acid play a pivotal role in extending tolerance to heat and drought stress [10,11]. For example, ABA levels increase significantly following exposure to higher temperatures in peas [12]. To counter the adverse effects of stress, the recruitment of essential metabolites and hormones can be compromised to cope with longer stress duration. Therefore, improving crop stress tolerance is deemed an important undertaking in developing eco-friendly agricultural approaches.

Silicon $(\mathrm{Si})$ is the second most abundant element in the earth's crust and has frequently been reported to be beneficial for plant growth and development [13, 14]. Due to its strong affinity for other ions, $\mathrm{Si}$ is commonly found as silicic acid $\left(\mathrm{H}_{4} \mathrm{SiO}_{4}\right)$, silicate $\left.\left(\mathrm{xM}_{12} \mathrm{OySiO}\right)_{2}\right)$, and silica $\left(\mathrm{SiO}_{2}\right)$ [15]. Si can increase plant tolerance to different abiotic and biotic stresses [16-18], such as salt and drought stress $[19,20]$, extreme temperature stress [21], nutrient deficiency [22], aluminum toxicity [23-26], disease resistance $[22,27]$, and pest resistance (e.g., from damage caused by wild rabbits, [28]. During stress, Si stimulates multiple response pathways, thereby activating antioxidants, enhancing mineral uptake and organic acid anions, exuding phenolic compounds, and regulating hormonal production [29-33].

Despite the known benefits of $\mathrm{Si}$ for plant growth under stress conditions, its underlying mechanisms in alleviating heat stress have rarely been investigated. To the best of our knowledge, only a few studies discussed the heat stress tolerance mechanisms induced by $\mathrm{Si}$ application. This study aimed to understand the mechanisms underlying heat stress tolerance to elucidate whether (i) Si extends stress aversion by maintaining active plant growth, (ii) it triggers the production and expression of mRNA transcripts related to antioxidative stress responses, (iii) it activates HSR by activating signaling cascades of HSP-related transcription factors and (iv) it influences stress-responsive ABA and SA syntheses. We also hypothesized that heat stress induces a reduction of plant growth and metabolism by overproducing ROS, stress-hormones, and osmotic pressure, which in turn can be minimized by exogenous $\mathrm{Si}$ application.

\section{Methods}

\section{Plant growth treatment and conditions}

Tomato seeds (Solanum lycopersicum L.) were obtained from Wadi Al-Lawami International, Oman that did not require any identification procedures and then thoroughly washed and soaked in autoclaved distilled water for $72 \mathrm{~h}$. Uniformly germinated seeds were transplanted into seed trays containing peat moss (moisture content 38.5\%, pH 4.5-5.5, electrical conductivity $2.0 \mathrm{dS} \mathrm{m} \mathrm{m}^{-1}$, bulk density $0.7-1.0 \mathrm{mg} \mathrm{m}^{-3}$, grain size $125-250 \mu \mathrm{m}$, with $91.1 \%$ organic matter: $\mathrm{N}, 800-2500 \mathrm{mg} \mathrm{kg}^{-1}$; $\mathrm{P}$, 150-850 $\mathrm{mg} \mathrm{kg}^{-1}$; $\mathrm{Na}, 340 \mathrm{mg} \mathrm{kg}^{-1}$; $\mathrm{NaCl}, 850 \mathrm{mg} \mathrm{kg}^{-1}$ ). Seedlings were irrigated with distilled water for 3 weeks to reach three internodes. Tomato seedlings of equal height and leaf number were then transplanted into larger pots $(10 \times 9 \mathrm{~cm})$ with $200 \mathrm{~g}$ of peat moss. Distilled water was applied for another week to acclimatize the plants before the start of the experiment. Four-week-old (third-internode) tomato seedlings were subjected to a completely randomized design with three replicates, each consisting of 15 seedlings subjected to exogenous Si treatment. Two conditions were tested: (i) normal growth and (ii) heat stress with $(+\mathrm{Si})$ and without $\mathrm{Si}$ $(-\mathrm{Si}$; only DW). To $+\mathrm{Si}$ plants, $50 \mathrm{~mL}$ of $1 \mathrm{mM} \mathrm{Si}$ was applied in the form of sodium metasilicate $\left(\mathrm{Na}_{2} \mathrm{SiO}_{3}\right)$, 
adjusted to $\mathrm{pH} 7$ using $\mathrm{HCl}$. Previous experiments on soybean, tomato, and rice showed that using a $1 \mathrm{Mm}$ Si concentration was most beneficial. After 15 days of $\mathrm{Si}$ application, plants were subjected to heat stress (43 \pm $\left.0.5^{\circ} \mathrm{C}\right)$. For heat stress, growth chamber conditions were adjusted to $\left(12 \mathrm{~h}\right.$ light $-30^{\circ} \mathrm{C}$ with $6 \mathrm{~h}$ heat $-43 \pm 0.5^{\circ} \mathrm{C}$; and $12 \mathrm{~h}$ dark $-30^{\circ} \mathrm{C}$ ) and $60 \%$ relative humidity. To mimic normal growth conditions, the growth chamber was set to a $12: 12$-h dark: light cycle at $30^{\circ} \mathrm{C}$ and $60 \%$ relative humidity). To gradually increase the temperature, hence changing the growth chamber conditions from those optimized for normal growth to a high-temperature cycle, a $60 \mathrm{~min}$ timer was used to increase the temperature gradually by $5 \pm 0.5^{\circ} \mathrm{C}$ from $30^{\circ} \mathrm{C}$ to $43 \pm 0.5^{\circ} \mathrm{C}$. Once heat stress conditions were achieved, $\mathrm{Si}$ was applied to the + Si group of tomato seedlings using the foliar method (10 $\mathrm{mL}$ daily), while $-\mathrm{Si}$ seedlings were treated with DW (10 $\mathrm{mL}$ daily). Both groups of seedlings were then left under heat stress conditions for 10 days, after which plant growth attributes (shoot length, stem diameter, and the number of leaves) were recorded and the shoot and aerial parts of the plant were harvested and stored in liquid nitrogen until further analysis.

\section{Chlorophyll pigments and leaf relative water content (LRWC)}

Photosynthetic pigments were extracted from $200 \mathrm{mg}$ of tomato seedling leaves and mixed with $80 \%$ acetone. Chlorophyll $a(\mathrm{Chl} a)$ and $b(\mathrm{Chl} b)$ contents were estimated according to a previously described method [34]. The absorbance of Chl $a$, Chl $b$ and carotenoids was recorded at 663, 645, and $480 \mathrm{~nm}$ respectively. Chlorophyll content was calculated using the following equations:

$$
\begin{aligned}
& \mathrm{Chl} a(\mathrm{mg} / \mathrm{g} \mathrm{FW})=[\{(12.7 \times \mathrm{A} 663)-(2.69 \times \mathrm{A} 645)\} / 1000 / \mathrm{W}] \times \mathrm{V} \\
& \mathrm{Chl} b(\mathrm{mg} / \mathrm{g} \mathrm{FW})=[\{(22.9 \times \mathrm{A} 645)-(4.68 \times \mathrm{A} 663)\} / 1000 \times \mathrm{W}] \times \mathrm{V}
\end{aligned}
$$

Where A is the absorbance and FW is the fresh weight of the leaf sample.

The LRWC was measured according to the method described by Cao, et al. [35]. Second leaves were excised and their fresh mass (FM) was also determined. After being left to float on deionized water for $5 \mathrm{~h}$, saturated mass (SM) was recorded. Leaves were then dried at $80^{\circ} \mathrm{C}$ to a constant weight and the dry mass (DM) was measured. The LRWC was calculated using the following equation:

$$
\operatorname{LRWC}(\%)=[(\mathrm{FM}-\mathrm{DM}) /(\mathrm{SM}-\mathrm{DM})] \times 100
$$

\section{Silicon analysis by inductively coupled plasma mass spectrometry (ICP-MS)}

$\mathrm{Si}$ was quantified with $0.05 \mathrm{~g}$ of ground samples of freeze-dried tomato roots and leaves according to the method described by Bilal, et al. [36] using inductively coupled plasma mass spectrometry (ICP-MS; Optima 7900DV, Perkin-Elmer, United States).

\section{RNA extraction and quantitative real-time PCR (qRT-PCR)}

The RNA extraction buffer $(0.25 \mathrm{M} \mathrm{NaCl}, 0.05 \mathrm{M}$ Tris$\mathrm{HCl}, \mathrm{pH} 7.5,20 \mathrm{mM}$, EDTA, 1\% w/v sodium dodecyl sulfate [SDS], $4 \% \mathrm{w} / \mathrm{v}$ polyvinyl pyrrolidone) was prepared using the protocol described by Liu, et al. [37]. Before adding the sample, $750 \mu \mathrm{L}$ of the extraction buffer and chloroform: isoamyl alcohol (CI; $24: 1 \mathrm{v} / \mathrm{v})$ were placed in a 2-mL RNase-free microcentrifuge tube, then $\beta$ mercaptoethanol $(40 \mu \mathrm{L})$ was added. Next, samples were carefully transferred to the buffer before thawing. The mixture was incubated at $20^{\circ} \mathrm{C}$ for $5-8$ min followed by centrifugation $12,000 \times g$ for $10 \mathrm{~min}$ at $4{ }^{\circ} \mathrm{C}$. Approximately $600 \mu \mathrm{L}$ of supernatant was transferred to a $2-\mathrm{mL}$ tube and the same volume of CI was added to all samples. The solutions were mixed gently and centrifuged at $12000 \times g$ for $10 \mathrm{~min}$ at $4{ }^{\circ} \mathrm{C}$. The upper layer was carefully transferred to a $1.5-\mathrm{mL}$ microcentrifuge tube and $1 / 10$ volume of $3 \mathrm{M}$ sodium acetate $(\mathrm{pH}=5.2)$ was added. An equal volume of absolute ethanol was added and the samples were incubated for $30 \mathrm{~min}$ at $4{ }^{\circ} \mathrm{C}$. After incubation, samples were centrifuged again at $12000 \times g$ for $10 \mathrm{~min}$ at $4{ }^{\circ} \mathrm{C}$ and RNA was recovered. The pellet was dissolved in $200 \mu \mathrm{L}$ of diethyl pyrocarbonate (DEPC)-treated water and $500 \mu \mathrm{L}$ of $10 \mathrm{M} \mathrm{LiCl}$ was added to the solution. The solutions were then mixed gently and placed on ice for $60 \mathrm{~min}$. Finally, samples were centrifuged once more at $12000 \times g$ for $10 \mathrm{~min}$ at $4{ }^{\circ} \mathrm{C}$ and the pellet was washed with $70 \%$ ethanol. After removing the ethanol, the pellet was air-dried, then dissolved in $50 \mu \mathrm{L}$ DEPC-treated water. The quality of the RNA was assessed via agarose gel electrophoresis and quantified using a Qubit RNA broad range kit.

The extracted RNA ( $>100 \mathrm{ng} / \mu \mathrm{L}$ ) was used for cDNA synthesis. High-Capacity cDNA Reverse Transcription Kit from Thermofisher was used for cDNA synthesis. Master Mix was prepared using 10X RT Buffer, 25X dNTPs Mix, MultiScribe ${ }^{\mathrm{m}}$ Reverse Transcriptase, 10X RT random primers, and nuclease-free water. RNA was added to Master Mix following the desired concentration (e.g., for each $100 \mathrm{ng} / \mu \mathrm{L}$ RNA, $10 \mu \mathrm{L}$ was taken for cDNA synthesis). PCR was performed in a thermocycler under specific conditions $\left(25^{\circ} \mathrm{C}\right.$ for $10 \mathrm{~min}, 37^{\circ} \mathrm{C}$ for $2 \mathrm{~h}$ and $85^{\circ} \mathrm{C}$ for $5 \mathrm{~min}$ ). The synthesized cDNA was refrigerated at $-80^{\circ} \mathrm{C}$ until further analysis.

The synthesized cDNA was used for gene amplification (Table 1). In total, 19 genes related to HSR, Si transport, drought tolerance, antioxidant enzymes, and the SA and ABA biosynthesis pathways were identified in each sample. Actin gene was used as a 
Table 1 List of the primer used for gene expression by qRT-PCR

\begin{tabular}{|c|c|c|c|c|c|}
\hline ID & Forward & Reversed & Encoding protein & Reference & $\begin{array}{l}\text { Accession } \\
\text { Number }\end{array}$ \\
\hline CAT & $\begin{array}{l}\text { GTCGATTGGTGTTG } \\
\text { AACAGG }\end{array}$ & $\begin{array}{l}\text { AGGACGACAAGGAT } \\
\text { CAAACC }\end{array}$ & Catalase & doi:10.4236/ajps.2010.11004 & M93719.1 \\
\hline APX & $\begin{array}{l}\text { GACTCTTGGAGCCC } \\
\text { ATTAGG }\end{array}$ & $\begin{array}{l}\text { AGGGTGAAAGGGAA } \\
\text { CATCAG }\end{array}$ & cytosolic ascorbate peroxidase & doi:10.4236/ajps.2010.11004 & DQ099420.1 \\
\hline POD & TTAGGGAGCAGTTTCCCACT & $\begin{array}{l}\text { AGGGTGAAAGGGAA } \\
\text { CATCAG }\end{array}$ & peroxidase & doi:10.4236/ajps.2010.11004 & DQ099421.1 \\
\hline GR & TTGGTGGAACGTGTGTTCTT & $\begin{array}{l}\text { TCTCATTCACTTCCCATC } \\
\text { CA }\end{array}$ & glutathione reductase & doi:10.4236/ajps.2010.11004 & AW033378 \\
\hline $\begin{array}{l}\mathrm{Cu} / \mathrm{Zn}- \\
\text { SOD }\end{array}$ & GGCCAATCTTTGACCCTITA & $\begin{array}{l}\text { AGTCCAGGAGCAAG } \\
\text { TCCAGT }\end{array}$ & SOD & doi:10.3390/molecules23030535 & Solyc11g066390 \\
\hline GST & TACTCGTITTGGGCTCGTT & $\begin{array}{l}\text { CACCGATTCAACTCCCTC } \\
\text { TG }\end{array}$ & GST & $\begin{array}{l}\text { doi:10.1371/ } \\
\text { journal.pone.0054880 }\end{array}$ & olyc01g086680 \\
\hline GPX & $\begin{array}{l}\text { ACGGAGCAAGCGACAATT } \\
\text { GACAAC }\end{array}$ & $\begin{array}{l}\text { CGATTGATTCACCGCAAA } \\
\text { GCTCGT }\end{array}$ & GPX & $\begin{array}{l}\text { doi:10.1371/ } \\
\text { journal.pone.0054880 }\end{array}$ & Solyc08g080940 \\
\hline NCED1 & $\begin{array}{l}\text { CTTATTTGGCTATCGCTG } \\
\text { AACC }\end{array}$ & $\begin{array}{l}\text { CCTCCAACTTCAAACTCA } \\
\text { TTGC }\end{array}$ & Synthesis of abscisic acid & Nitsch et al. (2009) & Z97215 \\
\hline ICS & TGCTGCCTCATGGACATACC & $\begin{array}{l}\text { TGCGAATGGGGATTITC } \\
\pi T\end{array}$ & isochorismate synthase & Not reported & $\begin{array}{l}\mathrm{XM}_{-} \\
019214147.2\end{array}$ \\
\hline PAL & $\begin{array}{l}\text { CACTTGTGAATGGCACAG } \\
\text { CA }\end{array}$ & $\begin{array}{l}\text { TCCGTTCATCACTT } \\
\text { CAGCAAA }\end{array}$ & $\begin{array}{l}\text { phenylalanine ammonia-lyase } \\
1\end{array}$ & Not reported & $\begin{array}{l}X_{-} \\
004234584.3\end{array}$ \\
\hline PR1b1 & $\begin{array}{l}\text { GCACTAAACCTAAAGAAA } \\
\text { AATGGG }\end{array}$ & $\begin{array}{l}\text { AAGTTGGCATCCCA } \\
\text { AGACATA }\end{array}$ & Signal pathway of salicylic acid & Tucci et al. (2011) & Y08804 \\
\hline PR-P2 & $\begin{array}{l}\text { GGAACAGGAACACAAGAA } \\
\text { ACAGTGA }\end{array}$ & $\begin{array}{l}\text { CCCAATCCATTAGTGTCC } \\
\text { AATCG }\end{array}$ & Signal pathway of salicylic acid & Tucci et al. (2011) & X58548 \\
\hline HsfA1a & $\begin{array}{l}\text { GGGATAAATGAGGC } \\
\text { AGCAAA }\end{array}$ & $\begin{array}{l}\text { TTGACCTGCAATTG } \\
\text { CTGAAG }\end{array}$ & HsfAla & doi: 10.1104/pp.15.01913. & Solyc08g005170 \\
\hline HsfA2 & CTCACCCCATTCAGGTGTTT & $\begin{array}{l}\text { TGCTGCAATGGACAATGA } \\
\text { AT }\end{array}$ & Hsfa2 & $\begin{array}{l}\text { https://doi.org/10.1104/pp.15. } \\
01913\end{array}$ & LOC101255223 \\
\hline SIHsfA3 & $\begin{array}{l}\text { AGATCCCTTGCAGGTAGC } \\
\text { TG }\end{array}$ & $\begin{array}{l}\text { TGATGGCAGTATCC } \\
\text { CAATGG }\end{array}$ & $\begin{array}{l}\text { Heat Stress Transcription } \\
\text { Factor }\end{array}$ & $\begin{array}{l}\text { doi:10.1371/ } \\
\text { journal.pone.0054880 }\end{array}$ & \\
\hline HsfA7 & $\begin{array}{l}\text { GCTTCTITTATCCATGGT } \\
\text { GTCC }\end{array}$ & $\begin{array}{l}\text { CTTGAACCTGGAAACTCT } \\
\text { TC }\end{array}$ & $\begin{array}{l}\text { Heat Stress Transcription } \\
\text { Factor }\end{array}$ & $\begin{array}{l}\text { doi:10.1371/ } \\
\text { journal.pone.0054880 }\end{array}$ & Solyc09g065660 \\
\hline HsfA1b & $\begin{array}{l}\text { GAAAGCTTGCACTG } \\
\text { ACGCAGG }\end{array}$ & $\begin{array}{l}\text { GGTCCGATATGATA } \\
\text { GATAGTG }\end{array}$ & $\begin{array}{l}\text { Heat Stress Transcription } \\
\text { Factor }\end{array}$ & $\begin{array}{l}\text { doi:10.1371/ } \\
\text { journal.pone.0054880 }\end{array}$ & Solyc03g097120 \\
\hline DREB2 & $\begin{array}{l}\text { ATGATAATAATGTCTACA } \\
\text { GAGCAA }\end{array}$ & $\begin{array}{l}\text { CTAATGTTGCCATAAAAA } \\
\text { ACTCTC }\end{array}$ & $\begin{array}{l}\text { dehydration responsive } \\
\text { element binding }\end{array}$ & DOI 10.1007/s13580-011-0125-5 & \\
\hline MAPK1 & $\begin{array}{l}\text { ATGCGCTTACAGAGGAAC } \\
\text { AGATG }\end{array}$ & $\begin{array}{l}\text { CGGACGGAATGCAC } \\
\text { ACATATATAC }\end{array}$ & enhanced drought tolerance & $\begin{array}{l}\text { https://doi.org/10.1007/s11240- } \\
\text { 017-1358-5 }\end{array}$ & AJ535702 \\
\hline
\end{tabular}

reference. Forward and reverse primers of 10 pM were used for all genes. For each sample, triplicate reactions were performed to minimize errors and contamination. The reaction was performed under the following conditions: $94{ }^{\circ} \mathrm{C}$ for $10 \mathrm{~min}, 35$ cycles of PCR reaction at $94{ }^{\circ} \mathrm{C}$ for $45 \mathrm{~s}, 65^{\circ} \mathrm{C}$ for $45 \mathrm{~s}, 72{ }^{\circ} \mathrm{C}$ for $1 \mathrm{~min}$. Finally, the extension temperature was set at $72{ }^{\circ} \mathrm{C}$ for another $10 \mathrm{~min}$. A threshold of 0.1 was set for gene amplification. Data were obtained in triplicates and was calculated using CT values and housekeeping gene fold expression patterns reported in Schmittgen and Livak [38].

\section{Determination of oxidative stress during heat stress}

The extent of lipid peroxidation based on malondialdehyde (MDA) was determined in a previous study [39]. In our assay, $10 \mathrm{mM}$ phosphate buffer ( $\mathrm{pH} 7$ ) was used to prepare the tissue homogenate. The reaction mixture consisted of $1.5 \mathrm{~mL}$ of $20 \%$ acetic acid (pH 3.5), $0.2 \mathrm{~mL}$ of $8.1 \% \mathrm{SDS}, 1.5 \mathrm{~mL}$ of $0.81 \%$ thiobarbituric acid (TBA), and $0.2 \mathrm{~mL}$ of tissue homogenate. The reaction tube was heated for $60 \mathrm{~min}$. The reaction mixture was then placed at room temperature for $15 \mathrm{~min}$, followed by the addition of $5 \mathrm{~mL}$ of the butanol: pyridine $(15: 1 \mathrm{v} / \mathrm{v})$ solution. The upper organic layer (i.e., the pink solution) was 
collected and the optical density was recorded at 532 $\mathrm{nm}$. Tetramethoxypropane was used as an external standard and the experiments were performed in triplicates.

The generation rate of $\mathrm{O}_{2}{ }^{-}$was measured using the method described in Gajewska and Skłodowska [40]. Fresh plant powder $(1 \mathrm{~g})$ was immersed in phosphate buffer ( $\mathrm{pH} 7)$ containing $10 \mathrm{mM}$ sodium phosphate, $0.05 \%(\mathrm{w} / \mathrm{v})$ nitrobluetetrazolium (NBT), and $10 \mathrm{mM}$ sodium azide $\left(\mathrm{NaN}_{3}\right)$. The mixture was kept for $1 \mathrm{~h}$ at room temperature, then, $5 \mathrm{~mL}$ of the solution was transferred into a new test tube and heated for $15 \mathrm{~min}$ at $85^{\circ} \mathrm{C}$ in a water bath. The solution was then cooled on ice and vacuum filtered. The absorbance of the sample was read at $580 \mathrm{~nm}$ with a spectrophotometer. The experiment was performed in triplicates.

\section{Quantification of antioxidant enzymes}

For the quantification of total protein, a protein extract was prepared by grinding $100 \mathrm{mg}$ of leaf sample with potassium phosphate buffer (100 mM; pH 6.8) containing $0.2 \mathrm{mM}$ EDTA. After centrifugation for $30 \mathrm{~min}$ at 12 , $000 \times g$, the supernatant was transferred to a new tube for the determination of total protein content. The protocol described by Bradford [41] was used to quantify total protein content. The assay was conducted at $595 \mathrm{~nm}$ on a spectrophotometer. The experiment was performed in triplicates.

The protocol established by Kar and Mishra [42] was slightly modified to determine the activity of the antioxidant enzymes peroxidase (POD), catalase (CAT), polyphenol oxidase (PPO), and ascorbate oxidase (APX). To quantify these enzymes, $100 \mathrm{mg}$ of powdered leaf sample was mixed with $0.1 \mathrm{M}$ phosphate buffer $(\mathrm{pH} 7)$. The resulting mixture was centrifuged at $10,000 \mathrm{rpm}$ and $4{ }^{\circ} \mathrm{C}$ for $30 \mathrm{~min}$ in a refrigerated centrifuge. To quantify POD, $100 \mu \mathrm{L}$ of the crude extract was combined with $0.1 \mathrm{M}$ potassium phosphate buffer $(\mathrm{pH} 6.8), 50 \mu \mathrm{L} \mathrm{H}_{2} \mathrm{O}_{2}$ $(50 \mu \mathrm{M})$, and $50 \mu \mathrm{L}$ pyrogallol $(50 \mu \mathrm{M})$. The reaction mixture was incubated at room temperature for $5 \mathrm{~min}$, followed by the addition of $\mathrm{H}_{2} \mathrm{SO}_{4}(\mathrm{v} / \mathrm{v})(5 \%)$. The extent of purpurogallin production was measured based on the optical density at $420 \mathrm{~nm}$. To quantify PPO, we used a similar reaction mixture to that used for POD quantification but added $\mathrm{H}_{2} \mathrm{O}_{2}(50 \mu \mathrm{M})$, and the final assay was conducted at $420 \mathrm{~nm}$. CAT activity was determined using the method developed by Aebi [43]: the protein mixture was combined with $10 \mathrm{mM}$ phosphate buffer (pH 7) and supplemented with $0.2 \mathrm{M} \mathrm{H}_{2} \mathrm{O}_{2}$. CAT activity was measured by the decrease in absorbance at $240 \mathrm{~nm}$ and expressed as $\mu \mathrm{g}$ of $\mathrm{H}_{2} \mathrm{O}_{2}$ released/mg protein/min. To assay APX activity, $100 \mathrm{mg}$ of fresh plant powder was immersed in $1 \mathrm{~mL}$ of $50 \mathrm{mM}$ phosphate buffer solution (pH 7) containing $1 \mathrm{mM}$ EDTA and $1 \mathrm{mM}$ ascorbic acid, followed by homogenization at $50 \mathrm{~Hz}$ for $30 \mathrm{~s}$. The resulting homogenates were centrifuged at $4830 \times g$ at $4{ }^{\circ} \mathrm{C}$ for $15 \mathrm{~min}$. Subsequently, the supernatant was combined with the phosphate buffer $(\mathrm{pH} 7)$ containing 0.3 $\mathrm{mM} \mathrm{H}_{2} \mathrm{O}_{2}$ and $15 \mathrm{mM}$ ascorbic acid. The reaction mixture was then analyzed spectroscopically at $290 \mathrm{~nm}$. One unit of APX was defined as the variable quantity of absorbance at $290 \mathrm{~nm}$ per minute.

\section{SA extraction and quantification}

SA was extracted and quantified from freeze-dried tomato samples according to the method developed by Seskar, et al. [44] and described by Shahzad, et al. [45]. The extracted samples were subjected to highperformance liquid chromatography (HPLC) performed using a Shimadzu device outfitted with a fluorescence indicator (Shimadzu RF-10AxL) with excitation at 305 $\mathrm{nm}$ and emission at $365 \mathrm{~nm}$, filled with a C18 reverse phase HPLC column (HP Hypersil ODS, particle size $5 \mu \mathrm{m}$, pore size $120 \AA$, Waters). The flow rate was maintained at $1 \mathrm{~mL} / \mathrm{min}$. The experiment was repeated three times and each time comprised three replications.

\section{$A B A$ extraction and quantification}

Endogenous ABA was extracted and quantified according to the modified protocol described by Shahzad, et al. [46] and Bilal, et al. [36]. Briefly, samples extracted from ground freeze-dried plants were supplemented with $[( \pm)-3,5,5,7,7,7-\mathrm{d} 6]-\mathrm{ABA}$ as an internal standard and further analyzed using gas chromatography-mass spectroscopy (GCMS; $6890 \mathrm{~N}$ network GC system) and a 5973-network mass selective detector (Agilent Technologies, Palo Alto, CA, USA). To expand the affectability of the method, spectra were recorded for the selected ions at $\mathrm{m} / \mathrm{z} 162$ and 190 for Me-ABA, and at m/z 166 and 194 for Me-[2H6]-ABA. Moreover, ABA was calculated from the value of the endogenous peak in comparison to the respective standard. The experiment was repeated three times and each time comprised three replications.

\section{Statistical analysis}

All experiments were performed in triplicates and data collected from each repetition were pooled together. All values are presented as the mean \pm standard deviation (SD). Means were analyzed using Duncan's multiple range (DMRT) tests, with significance set at $P<0.05$. All analyses were conducted using SAS 9.1 software (Cary, NC, USA).

\section{Results}

Effects of exogenous Si application on tomato plant growth parameters

In this study, exogenous $\mathrm{Si}$ application increased growth parameters under both normal and heat stress 
conditions. The results showed that exogenous Si application significantly increased shoot length under normal and heat stress conditions compared to $-\mathrm{Si}$ (36 and $31 \%$, respectively; $P<0.001$; Fig. 1a). Pronounced wilting of the leaf was prolific in $-\mathrm{Si}$ plants compared to the condition in $+\mathrm{Si}$ plants. This was further validated by the significant increase in stem diameter in $+\mathrm{Si}$ seedlings under both conditions (36 and $72 \%$, respectively; $P<0.001$; Fig. 1c). This suggests an ameliorative effect of $\mathrm{Si}$ on plant growth under heat stress. Additionally, shoot biomass also significantly increased in $+\mathrm{Si}$ plants under normal and heat stress conditions compared to the results for $-\mathrm{Si}$ plants (61 and 70\%, respectively; $P<0.001$; Fig. 1b; Supplementary Fig. S1A). The root length, fresh, and dry biomass decreased under heat stress. However, $+\mathrm{Si}$ application significantly improved the root morphological traits and increased root length compared to the levels in $-\mathrm{Si}$ plants under heat stress and normal conditions (41 and 62\%, respectively; $P<0.001$; Fig. 1e), as shown by the secondary and tertiary root development. Similarly, Si application significantly increased the root and fresh root weights in both normal and heat stress conditions (42 and 28\%, respectively, $P<0.001 ; 74$ and $62 \%$, respectively, $P<$ 0.001; Fig. 1d; Supplementary Fig. S1B).

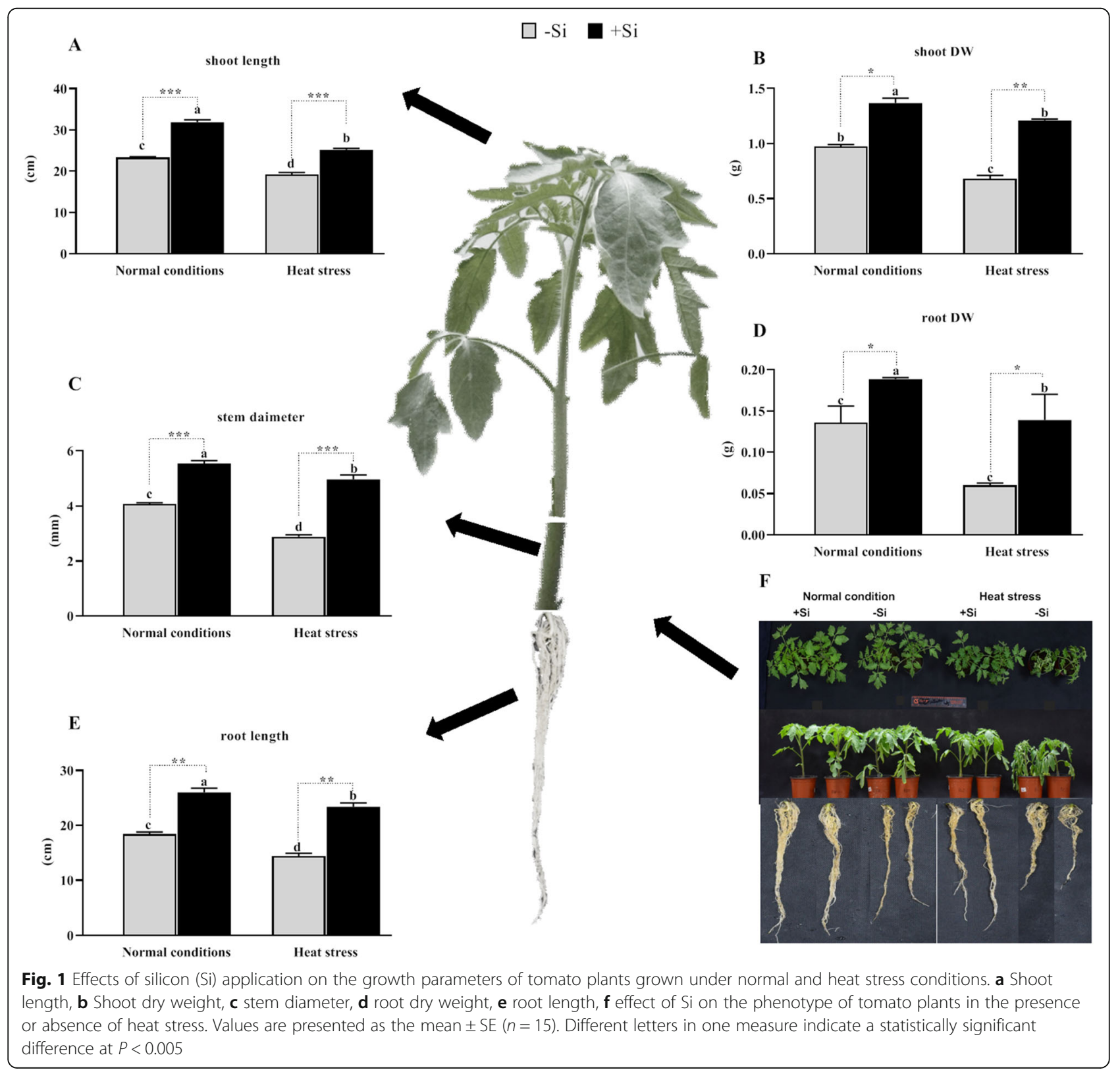


Effects of exogenous Si application on chlorophyll pigments and relative water content

Si application significantly increased Chl $a$ (27 and 38\%, $P<0.001$ ), Chl $b$ (27 and 38\%, $\mathrm{P}<0.001$ ), and carotenoid (27 and 39\%, $\mathrm{P}<0.001$ ) content in normal and heatstressed tomato plants. By contrast, significant reductions in Chl $a$, Chl $b$, and carotenoid content $(19,19$, and $21 \%$ ) were recorded in heat-stressed $-\mathrm{Si}$ plants (Fig. 2a-c). This suggests that $\mathrm{Si}$ mitigated the adverse effects of heat stress by improving Chl $a$, Chl $b$, and carotenoids. Given the predicted impact of heat stress on plant osmotic potential, we also analyzed LRWC. A significant increase of 13 and $20 \%(P<0.001)$ in the water content was recorded in $+\mathrm{Si}$ plants compared to $-\mathrm{Si}$ plants under normal and heat-stressed conditions, respectively (Fig. 2d). Heat stress increased the plant's vulnerability to water stress and plants with an adequate supply of Si were more hydrated than -Si plants.

\section{Effects of Si on superoxide anion $\left(\mathrm{O}_{2}^{-}\right)$and MDA}

The ROS-induced peroxidation of lipid membranes is a reflection of stress-induced cell damage [47]. One of the main products of ROS is $\mathrm{O}_{2}^{-}$, which causes significant damages to cellular organelles and their respective functions [48]. In this study, we found that the production of $\mathrm{O}_{2}{ }^{-}$increased significantly by $77.9 \%(P<0.001)$ in heatstressed conditions in $-\mathrm{Si}$ plants compared to the production in normal growth conditions (Fig. 3a), while in $+\mathrm{Si}$ plants, the production of $\mathrm{O}_{2}{ }^{-}$increased by only $30.2 \%$ under heat stress. This increase was significantly lower than that in $-\mathrm{Si}$ plants, indicating the regulatory role of + Si during heat stress and the generation of ROS.

Furthermore, we quantified the level of MDA under $\mathrm{Si}$ and $+\mathrm{Si}$ conditions (Fig. 3b). MDA is a by-product of lipid peroxidation and is an indirect indicator of oxidative stress and damage to the lipid bilayer [49]. MDA significantly decreased by 56.0 and $64.5 \%(P<0.001)$ in $+\mathrm{Si}$ plants compared to $-\mathrm{Si}$ plants under normal and heat-stressed conditions, respectively. This suggests that Si subverted the process of lipid peroxidation compared to - Si during heat stress.

\section{Antioxidant enzyme synthesis and mRNA gene expression profiling in $-\mathrm{Si}$ and + Si plants}

Our experiments revealed an increased production of POD, CAT, SOD, and PPO in + Si plants compared to $\mathrm{Si}$ plants in both the normal and heat-stressed conditions. However, under normal growth conditions, CAT activity was lower in $-\mathrm{Si}$ plants but increased in $+\mathrm{Si}$ plants under heat stress. Under normal growth conditions, POD activity was also significantly higher in $+\mathrm{Si}$ plants compared to $-\mathrm{Si}$ plants $(79.2 \%, \quad P<0.001)$; however, POD activity only increased by $51.77 \%$ under heat-stressed conditions (Fig. 3c). Furthermore, the
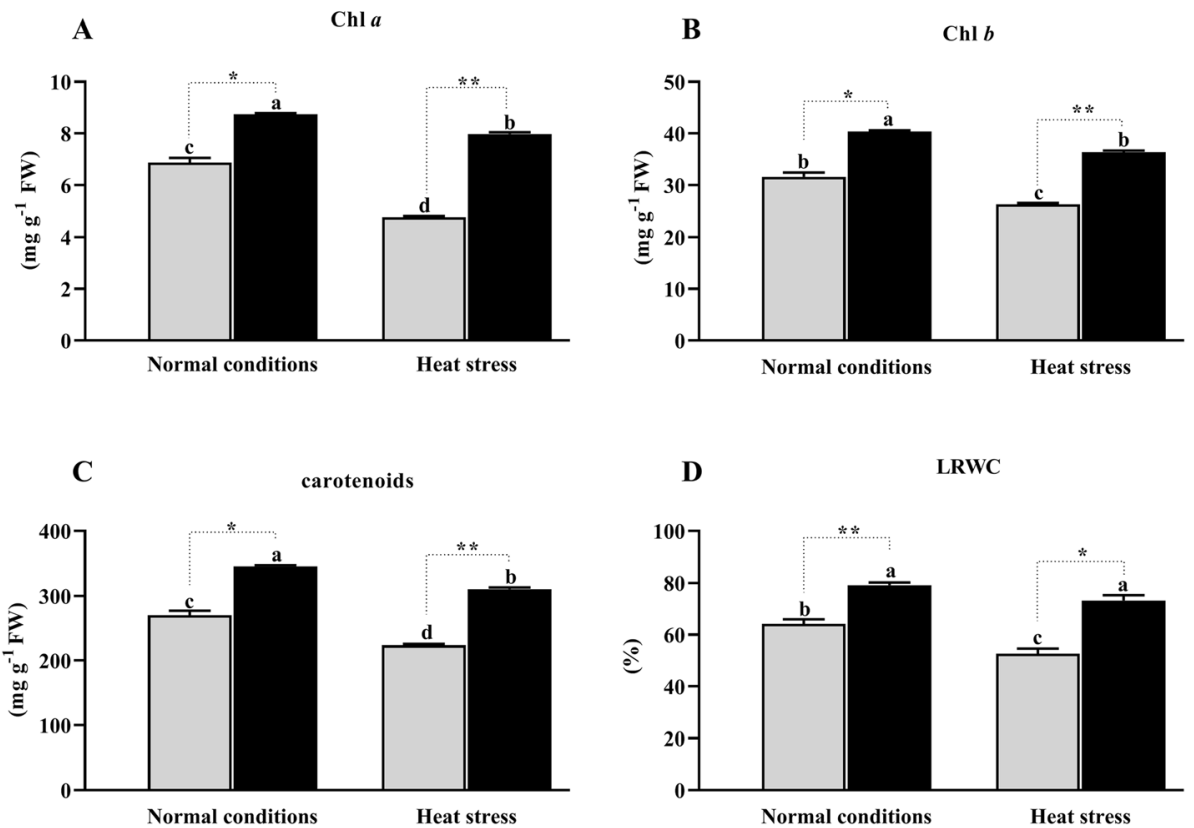

Fig. 2 Effects of Si application on photosynthesis. a Chlorophyll $a$ (b) Chlorophyll b (c) Carotenoids (d) leaf relative water content (LRWC) under control and heat stress conditions. Values are presented as the mean \pm SE $(n=6)$. Different letters in one measure indicate a statistically significant difference at $P<0.005$ 


\section{$-\mathrm{Si} \square+\mathrm{Si}$}
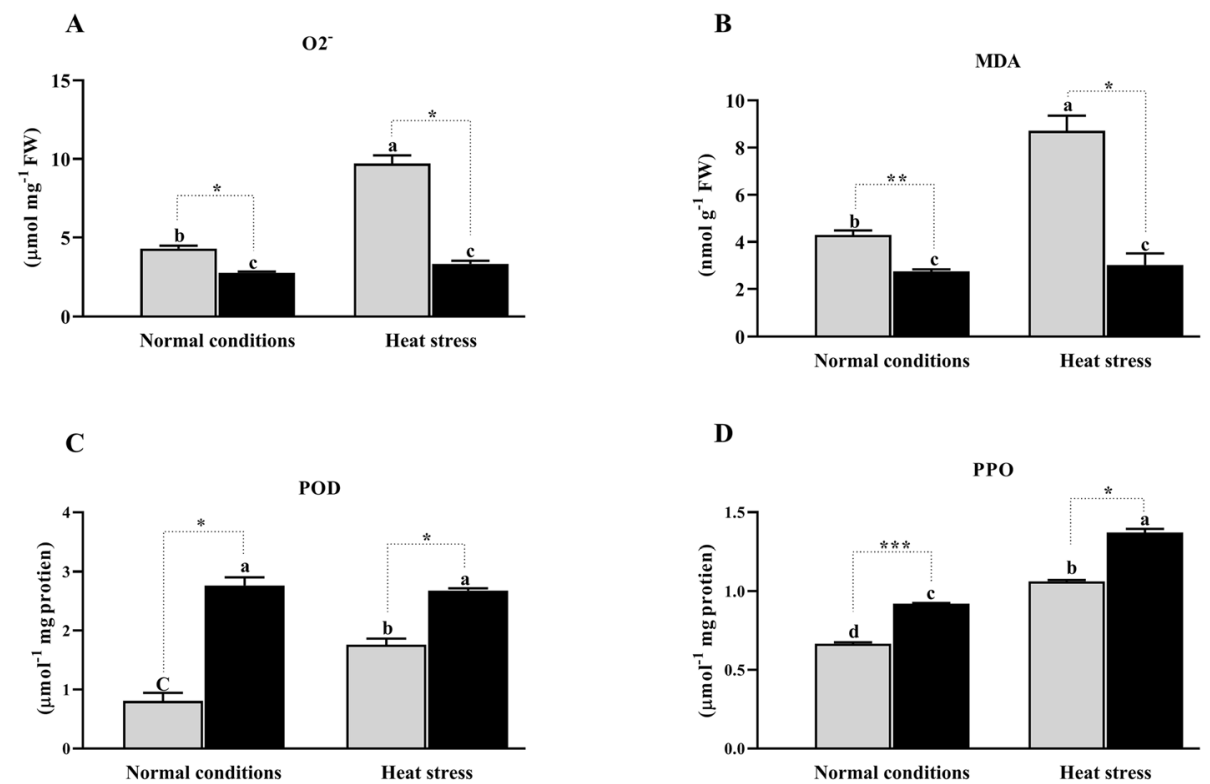

D
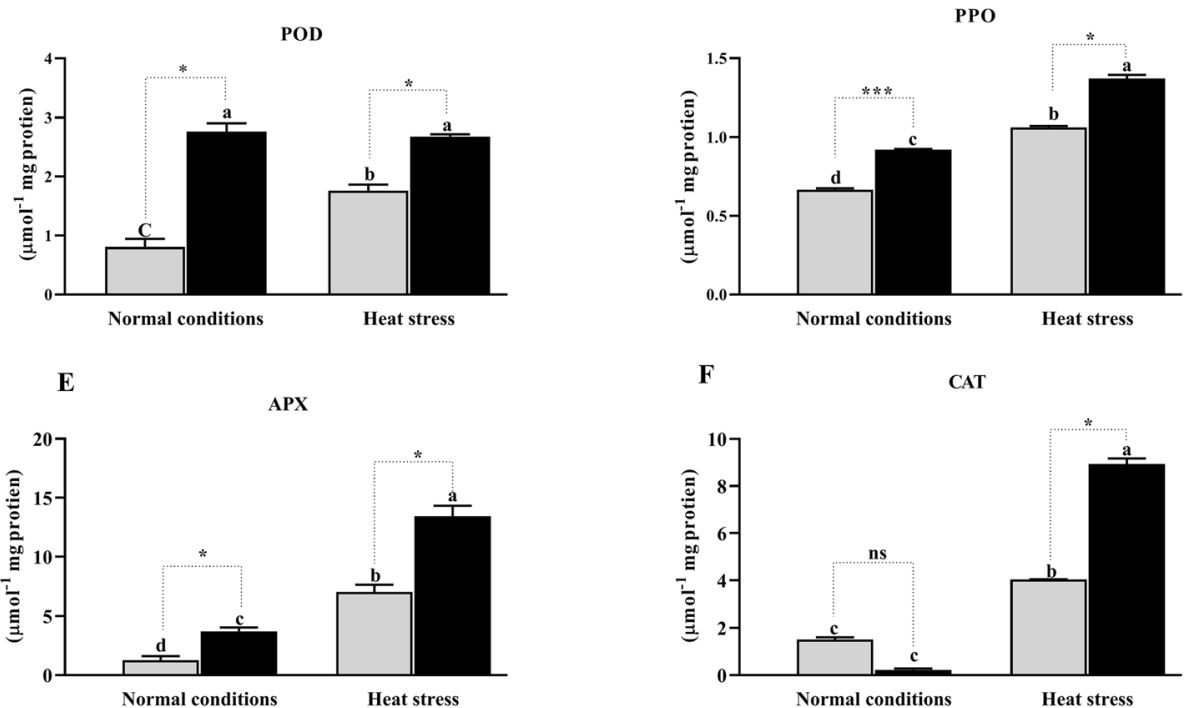

Fig. 3 Effects of Si application on stress-related parameters. a Malondialdehyde (MDA) content and (b) In situ O2-, c Peroxidase (POD), d Polyphenol oxidase (PPO), e ascorbate peroxidase (APX) and (f) catalase (CAT). Each data point presents the mean of three replicates. Means denoted by different letters are significantly different $(P<0.05)$

activity of POD in $-\mathrm{Si}$ and $+\mathrm{Si}$ plants under heat stress increased by 35.4 and $14.6 \%$, respectively, compared to POD activity under normal conditions.

Likewise, in $+\mathrm{Si}$ tomato seedlings, PPO, APX, and CAT activities increased by $29.24,91.2$, and $121.6 \%(P<$ 0.001 ) under heat-stressed conditions compared to $-\mathrm{Si}$ plants (Fig. 3d-f). Under normal growth conditions, however, the activity of PPO and APX increased by 39.4 and 189.1\% $(P<0.001)$, respectively, but the activity of CAT decreased by $86.5 \%(P<0.001)$ in $+\mathrm{Si}$ compared to $-\mathrm{Si}$ plants. Figure $3 \mathrm{~d}-\mathrm{f}$ show that the activity of PPO, APX, and $\mathrm{CAT}$ in $-\mathrm{Si}$ and $+\mathrm{Si}$ plants under heat stress increased by $60.6,449.2$, and $166.8 \%(P<0.001)$ compared to the normal conditions.

To investigate the molecular mechanisms underlying the effects of $\mathrm{Si}$ on antioxidant enzymes in tomato plants during heat-stressed conditions, we evaluated the relative mRNA expression levels of the SICAT, SlAPX, SlPOD, SlGR, SlSOD, SlGPX, and SlGST genes (Fig. 4).
The relative expression levels five of these genes (except SIGR and SIGPX) were significantly upregulated when Si tomato plants were exposed to heat stress $(P<0.001$; Fig. 4a-g). Interestingly, the $+\mathrm{Si}$ tomato plants exposed to heat stress showed high relative expression levels of SICAT (2.3-fold), SIAPX (2.9-fold), SIPOD (1.7-fold), SIGR (6.6-fold), SISOD (9.7-fold), SIGPX (2.2-fold), and SlGST (16.7-fold) compared to that recorded in $-\mathrm{Si}$ plants. Under normal growth conditions, the relative expression levels of SlPOD, SlGR, and SlGST genes increased significantly by $0.86,3.5$, and 5.08 -fold $(P<$ $0.001)$ in $+\mathrm{Si}$ plants compared to $-\mathrm{Si}$ plants, while SlCAT was downregulated by 0.21 -fold. However, no significant increase was noted in the genes SLAPX, SlSOD, and $\operatorname{SlGPX}(0.69,1.85$, and 0.95 -fold $)$ respectively (Fig. 4a-g). The increase in the relative gene expression levels in $+\mathrm{Si}$ tomato plants compared to those of $-\mathrm{Si}$ plants indicates that $\mathrm{Si}$ improved the expression of genes involved in antioxidant enzyme production. 
A

SICAT

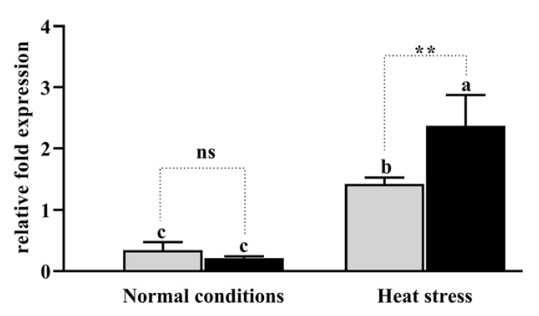

C

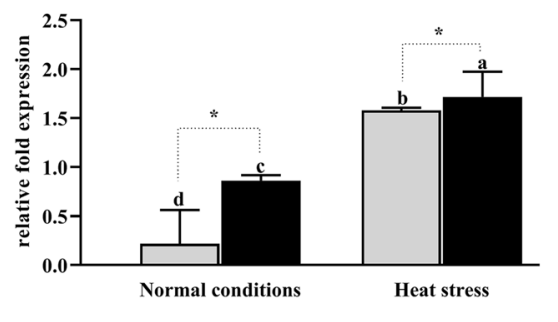

E

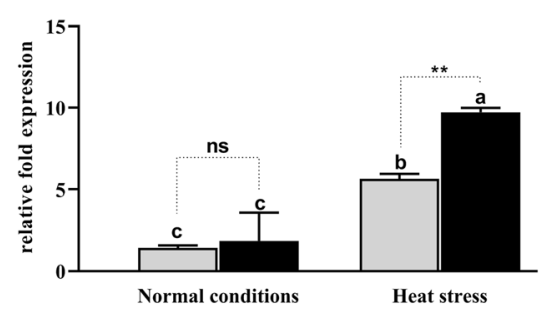

SIGST

G

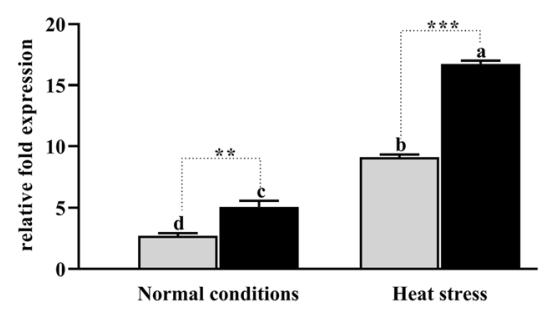

B

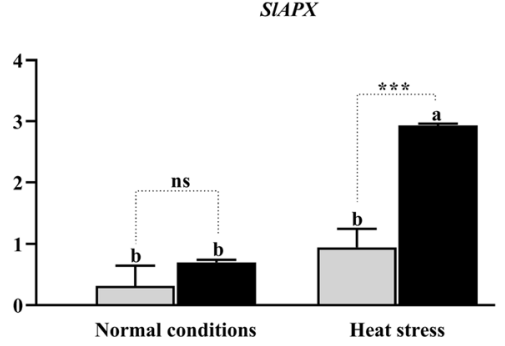

D SIGR

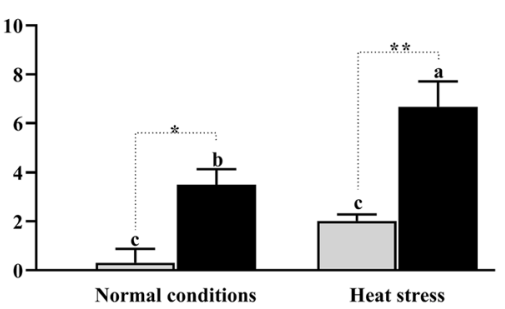

F

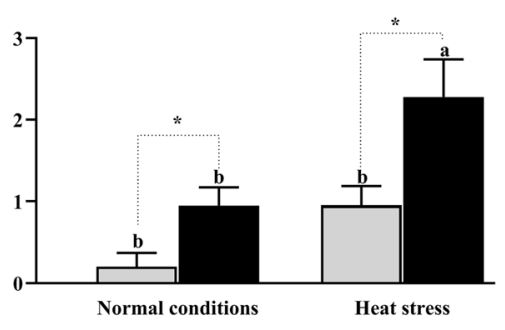

Fig. 4 Effect of Si application on the transcript of genes encoding antioxidant enzymes. a SICAT, b SIAPX, c SIPOD, d SLGR, e SISOD, f SIGPX, and (g) SIGST. Each data point presents the mean of three replicates. Means denoted by different letters are significantly different $(P<0.05)$

Effects of Si on relative expression level of genes coding for HSFs and stress-related proteins

$H s f s$ regulate the expression of HSPs. In this study, we evaluated the relative mRNA expression level of SlHsfA1a, SlHsfA1b, SlHsfA2, SlHsfA3, and SlHsfA7 under normal and heat-stressed conditions in $+\mathrm{Si}$ and Si plants (Fig. 5a-e). Our results showed that the expression of $H s f s$ and stress-related genes was upregulated by warm temperatures. In $+\mathrm{Si}$ plants, a high relative expression level was recorded for SlHsfA1a (7.7-fold), SlHsfA1b (10-fold), SlHsfA2 (5.5-fold), SlHsfA3 (6.6-fold), and
SlHsfA7 (10.62-fold) under heat stress compared to $-\mathrm{Si}$ plants. However, under normal growth conditions, there was no significant increase in the relative expression levels of $H s f A 1 b$ and $H s f A 3$ in + Si plants compared to Si plants. Under normal growth conditions, HsfAla and $H s f A 3$ were downregulated in $+\mathrm{Si}$ plants compared to $\mathrm{Si}$ plants (Fig. 5a-e). Hence, the exogenous Si-mediated increased the expression of $H s f s$ and stress-responsive genes under heat stress. This ultimately triggered the HSR in tomato plants by activating Hsps, which consequently led to the prevention of lipid peroxidation and 


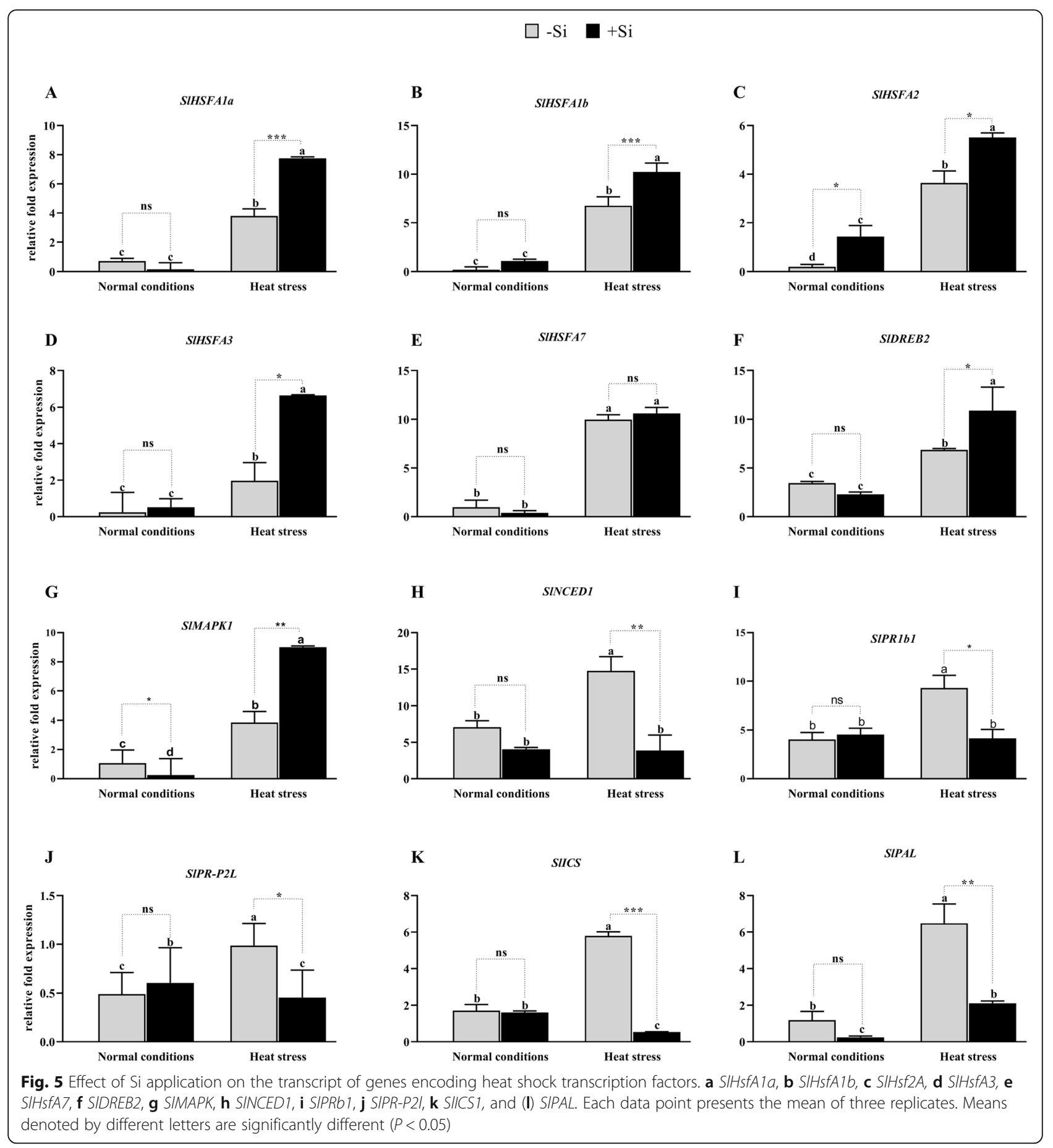

the generation of excessive reactive radicals. Furthermore, the activated HSR further increased the secretion of plant antioxidant enzymes.

The overexpression of transcription factors can modulate a wide range of signaling pathways involved in stress tolerance [50]. The dehydration-responsive elementbinding proteins (SIDREB2) transcription factors are regulated by abiotic stress-related genes, thus providing the plant with tolerance to various environmental stimuli [51]. The products of these genes are thought to function both in stress tolerance and in the regulation of gene expression and signal transduction of genes related to stress response [52, 53]. Transcription factor SIDREB2 was weakly expressed in the control plants and was stimulated by heat stress in both $-\mathrm{Si}$ and $+\mathrm{Si}$ plants by 6.88-fold and 10.91-fold, respectively. These results 
suggest that $\mathrm{Si}$ application increased the expression of SIDREB2, thus improving tomato seedlings tolerance to heat stress (Fig. 5f). Previous studies revealed that protein kinases play a similar role as calcium-dependent protein kinases and mitogen-activated protein kinases (MAPKs) in response to abiotic stress [54]. In this study, we found that the expression of SlMAPKs was induced by heat stress (3.85-fold) in -Si plants, increasing by 9 fold in + Si plants under heat stress (Fig. $5 \mathrm{~g}$ ).

\section{Effects of Si on endogenous phytohormones during heat stress}

Plants respond to various abiotic and biotic stressors through alterations in hormonal homeostasis, biosynthesis rate, stability, content, and cell compartmentalization [55]. Phytohormones play an important role in plant growth and development and the current literature suggests these also play a role in the plant's response to various stresses [56]. In this study, we quantified endogenous $\mathrm{ABA}$ and $\mathrm{SA}$ hormones in $+\mathrm{Si}$ and -Si plants under both normal and heat stress conditions. The results revealed that $-\mathrm{Si}$ plants had significantly higher concentrations of ABA (265.91 $\left.\mathrm{ng} \mathrm{g}^{-1} \mathrm{FW}\right)$ and SA (11.34 $\left.\mathrm{ng} \mathrm{g}^{-1} \mathrm{FW}\right)$ compared to + Si plants under normal growth conditions (141.48 and $7.53 \mathrm{ng} \mathrm{g}^{-1} \mathrm{FW}$, respectively). Furthermore, the application of Si reduced ABA content significantly in tomato seedlings under both the normal and heat stress conditions by 74 and $44 \%$, respectively. Similarly, SA content was reduced by 19 and $32 \%$ in plants treated with $\mathrm{Si}$ compared to the level in -Si plants under normal and heat stress conditions, respectively (Fig. $6 \mathrm{a}$ and $\mathrm{b}$ ). Our findings indicate that $+\mathrm{Si}$ plants produced less $\mathrm{ABA}$ and $\mathrm{SA}$, which might be the reason they experienced higher tolerance and a lower amount of heat stress.

The effects of heat stress and exogenous $\mathrm{Si}$ on SA pathway-related genes (SlR1b1, SlPR-P2, SlICS, and $S I P A L)$ and ABA (SINCEDI) were examined using qRTPCR (Fig. 5h-l). The change in expression of SlR1b1, SIPrP2, SIICS, and SIPAL marker genes involved in the SA biosynthesis pathway was strongly and moderately downregulated in the $+\mathrm{Si}$ and $-\mathrm{Si}$ plants, respectively, under heat stress conditions. Interestingly, these results concur with those observed for the SA levels. However, under normal growth conditions, SIR1b1 and SIPR-P2 were slightly upregulated in $+\mathrm{Si}$ plants compared to $-\mathrm{Si}$ plants, while SIICS and SIPAL were downregulated, albeit not significantly. The SA signaling pathway appears to be activated under heat stress; however, in the current study, the exogenous application of $\mathrm{Si}$ resulted in the downregulation of this pathway. Such results are perfectly consistent with the fact that plant antioxidant capacity is inversely proportional to SA concentration. Furthermore, high concentrations of SA cause cell death

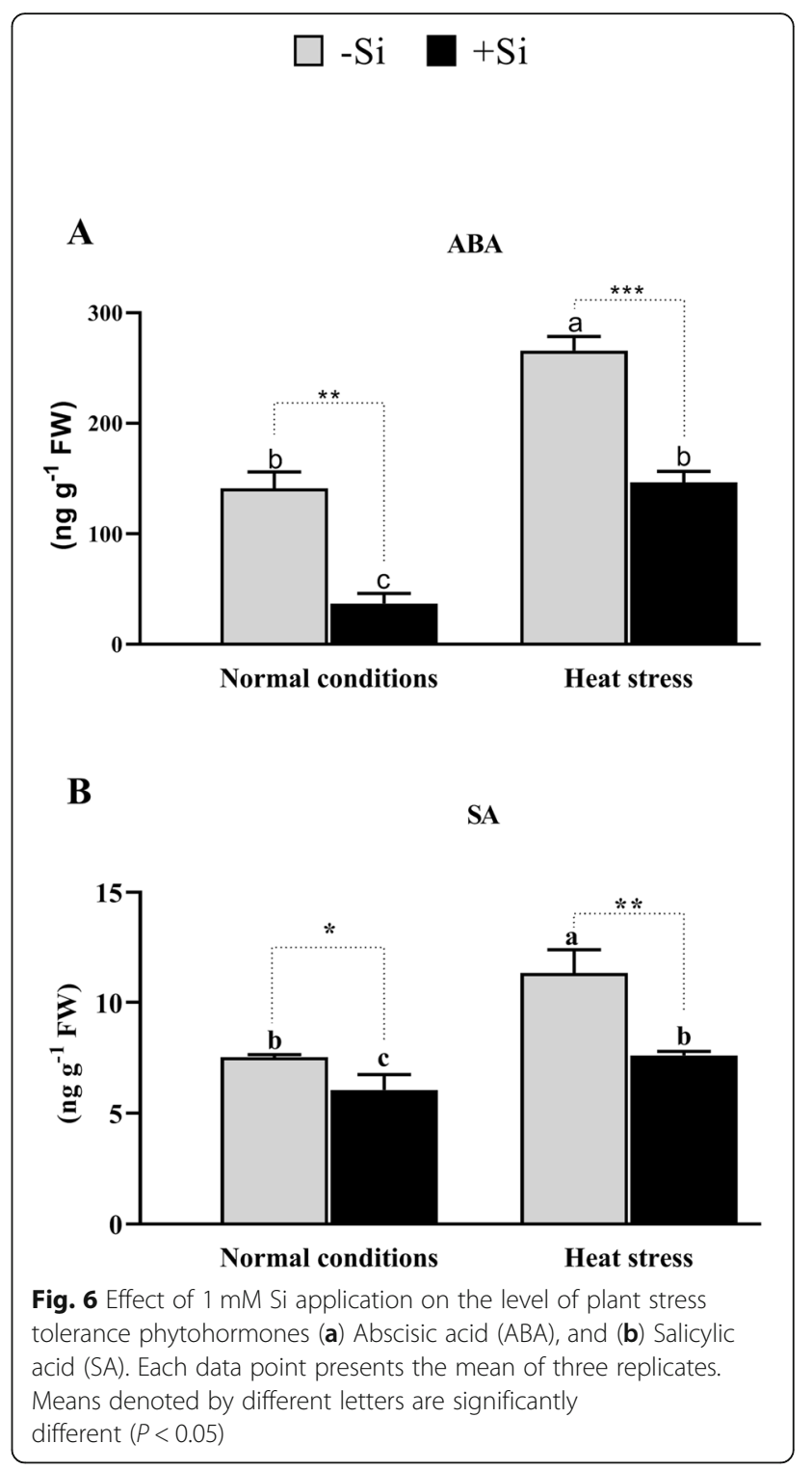

or increase vulnerability to abiotic stress. Hence, Si application reduced the biosynthesis of SA, which indirectly enhanced the production of antioxidant enzymes.

\section{$\mathrm{Si}, \mathrm{Na}$, and $\mathrm{K}$ concentrations in tomato plants under heat stress conditions}

$\mathrm{Si}$, $\mathrm{Na}$, and $\mathrm{K}$ concentrations were measured in the leaves of $+\mathrm{Si}$ and $-\mathrm{Si}$ tomato plants after harvest. Unsurprisingly, Si concentration was significantly higher in $+\mathrm{Si}$ plants compared to -Si plants in both the normal and heat stress conditions (5.2-fold and 6.1-fold higher, respectively, Table 2). This result was further validated at the gene expression level by investigating the relative expression of the Low Silicon 1 and 2 (SlLsi1 and SlLsi2) genes. As shown in Fig. $7 \mathrm{a}$ and $\mathrm{b}$, exogenous $\mathrm{Si}$ 
Table 2 Concentrations of Si, Na and $\mathrm{K}$ in the tomato shoot under normal and heat stress conditions

\begin{tabular}{|c|c|c|c|}
\hline \multirow[t]{2}{*}{ Treatments } & \multicolumn{3}{|c|}{ Concentration $\left(\mu \mathrm{mol} \mathrm{g}^{-1}\right)$} \\
\hline & $\mathrm{Si}$ & $\mathrm{Na}$ & K \\
\hline Normal condition $(+\mathrm{Si})$ & $2772.82 \pm 10.3^{b}$ & $1071.85 \pm 17.3^{\mathrm{a}}$ & $32,703.64 \pm 165.3^{\circ}$ \\
\hline Normal condition (-Si) & $563.06 \pm 17.9^{c}$ & $1080.43 \pm 55.6^{b}$ & $25,561.12 \pm 122.8^{\circ}$ \\
\hline Heat stress $(+\mathrm{Si})$ & $3693.89 \pm 39.3^{a}$ & $1270.98 \pm 99.7^{a}$ & $31,995.73 \pm 16.4^{b}$ \\
\hline Heat stress $(-S i)$ & $601.96 \pm 31.1^{c}$ & $1210.23 \pm 85.1^{a}$ & $20,002.39 \pm 79.4^{d}$ \\
\hline
\end{tabular}

Mean \pm standard error from three replications per treatment. In the column, the same letters indicate No significant difference $(P>0.05)$ by Duncan's Multiple Range Test (DMRT)

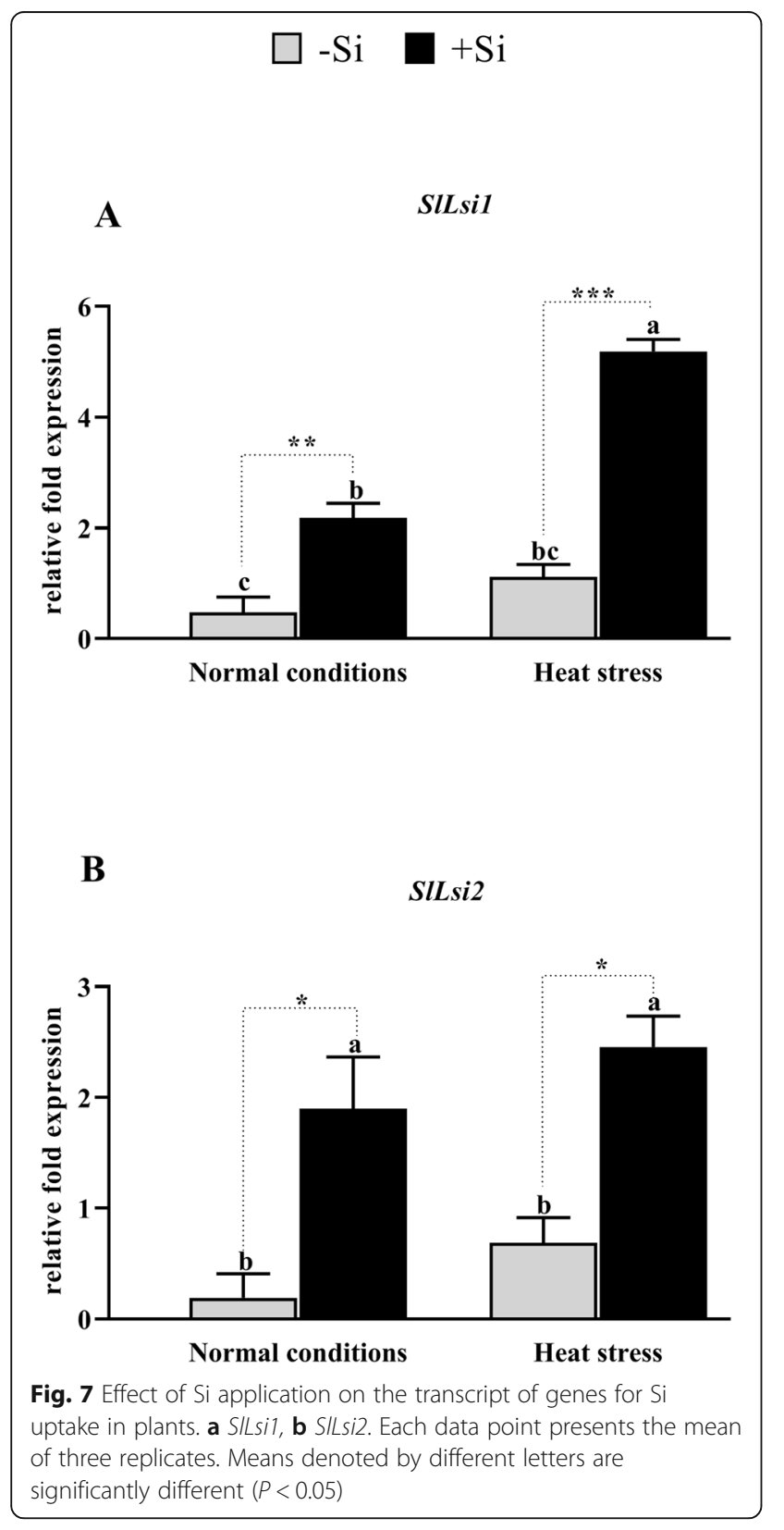

application improved the expression of SlLsi1 (2.1 and 5.1-fold) and SlLsi2 (1.9 and 2.4-fold) under both the normal and heat stress conditions, respectively. On the other hand, $\mathrm{Na}$ concentration in the leaves of the tomato plants was not significantly different between $+\mathrm{Si}$ and $\mathrm{Si}$ plants. However, the $\mathrm{Na}$ concentration was slightly higher in the $+\mathrm{Si}$ plants. This result indicates that exogenous $\mathrm{Na}$ application in the form of silicate did not increase $\mathrm{Na}$ concentration in the leaves of the tomato plants. However, Si significantly $(P<0.001)$ improved the uptake of $\mathrm{K}$ from the soil by approximately 0.6 to 1 fold (Table 2).

\section{Discussion}

Heat stress severely hinders crop production, causing substantial losses to the economy and endangering global food security [57-60]. Similarly to trends shown in other crops, it also negatively affects the growth and productivity of tomato plants [61-63]. Our findings demonstrate that exogenous $\mathrm{Si}$ application can mitigate the adverse effects pf heat stress in tomato plants by improving plant growth attributes, such as shoot length and biomass production. Similar findings were previously reported in Cucumis sativus L. [64], Nephrolepis exaltata L. [65], and Oryza sativa L. [66]. However, little is known about this phenomenon in tomato plants. The results presented in this study concur with those of previous reports by Mahdieh, et al. [67], Abbas, et al. [68], and Chen, et al. [69], where the application of exogenous $\mathrm{Si}$ alleviated the negative effects of abiotic stress and restored plant growth. The growth impacts were inferred from the increased levels in the concentration of photosynthetic pigments (Chl $a$, Chl $b$, and carotenoids) in $\mathrm{Si}+$ heat-stressed plants, while studies by [70], Wang, et al. [71], and Chalanika De Silva and Asaeda [72] showed that these concentrations were reduced by heat stress. These reductions were associated with the reduced production of ROS and thereby indirectly representative of the plants stress level [72, 73]. Furthermore, heat stress drastically decreased LRWC by inducing physiological water-deficit. On the other hand, Si application increased LRWC, which led to the increase in 
photosynthetic pigments observed in the current study. A similar finding was reached by previous studies following during heat stress [74], salinity [75], drought stress [76], and osmotic stress [77]. Similarly to other abiotic stresses, heat stress increased ROS production that consequently oxidize membrane lipids $[78,79]$ as high concentrations of MDA and $\mathrm{O}_{2}^{-}$in -Si plants were observed compared to $+\mathrm{Si}$ plants. The triggering of both molecules can lead to the disruption of activities of antioxidant enzymes [80]. Our results were similar those observed after Si application on Hordeum vulgare L. [80], Cicer arietinum L. [80], and Nephrolepis exaltata [65].

Plants have evolved an effective antioxidant system using POD, CAT, SOD, PPO, and APX enzymes to eliminate stress-induced excess ROS, thereby protecting the cells from the deleterious effects of oxidation reactions [81]. CAT, APX, and POD antioxidants are known for the dismutation of hydrogen peroxide to water and molecular oxygen in cells [82], as well as the elimination of stress-induced ROS directly or indirectly via the production of ascorbate and glutathione [83]. In this study, we found that the activities of ROS-eliminating enzymes changed significantly. All of the antioxidant enzymes examined in this study, including CAT, POD, PPO, and APX increased significantly in plants exposed to heat stress. However, under normal growth conditions, $-\mathrm{Si}$ plants showed higher CAT activity compared to $+\mathrm{Si}$ plants. This unusual regulation of CAT activity has been reported in several studies [84, 85]. +Si plants show enhanced CAT activity during heat stress compared to normal conditions (Fig. 8), concurring with previous findings $[83,86,87]$. The roles of $\mathrm{Si}$ in genes encoding for antioxidant enzymes have only been studied in a very narrow range. In this study, we elucidated the effects of $\mathrm{Si}$ on genes encoding for antioxidant enzymes, such as SlCAT, SlAPX, SIPOD, SlGR, SlSOD, SlGPX, and SlGST genes. Our findings revealed that Si application in heatstressed tomato plants increased the relative expression of SlCAT, SlAPX, SlPOD, SlGR, SlSOD, SlGPX, and SlGST genes, in line with previous reports by Sahebi, et al. [88] and Alberto, et al. [89]. Ma, et al. [90] reported that $\mathrm{Si}$ application induces high stress tolerance in plants by upregulating the antioxidant systems of plants.

Heat stress also influences the translocation of essential nutrients [91] and the resulting imbalance can either increase or decrease them. For example, growth inhibition is correlated with excessive $\mathrm{Na}^{+}$concentration and $\mathrm{K}^{+}$deficiency (Fig. 8). Either high $\mathrm{Na}$ or low $\mathrm{K}$ in the soil are considered as a stress condition that can severely affect plant performance and agricultural productivity

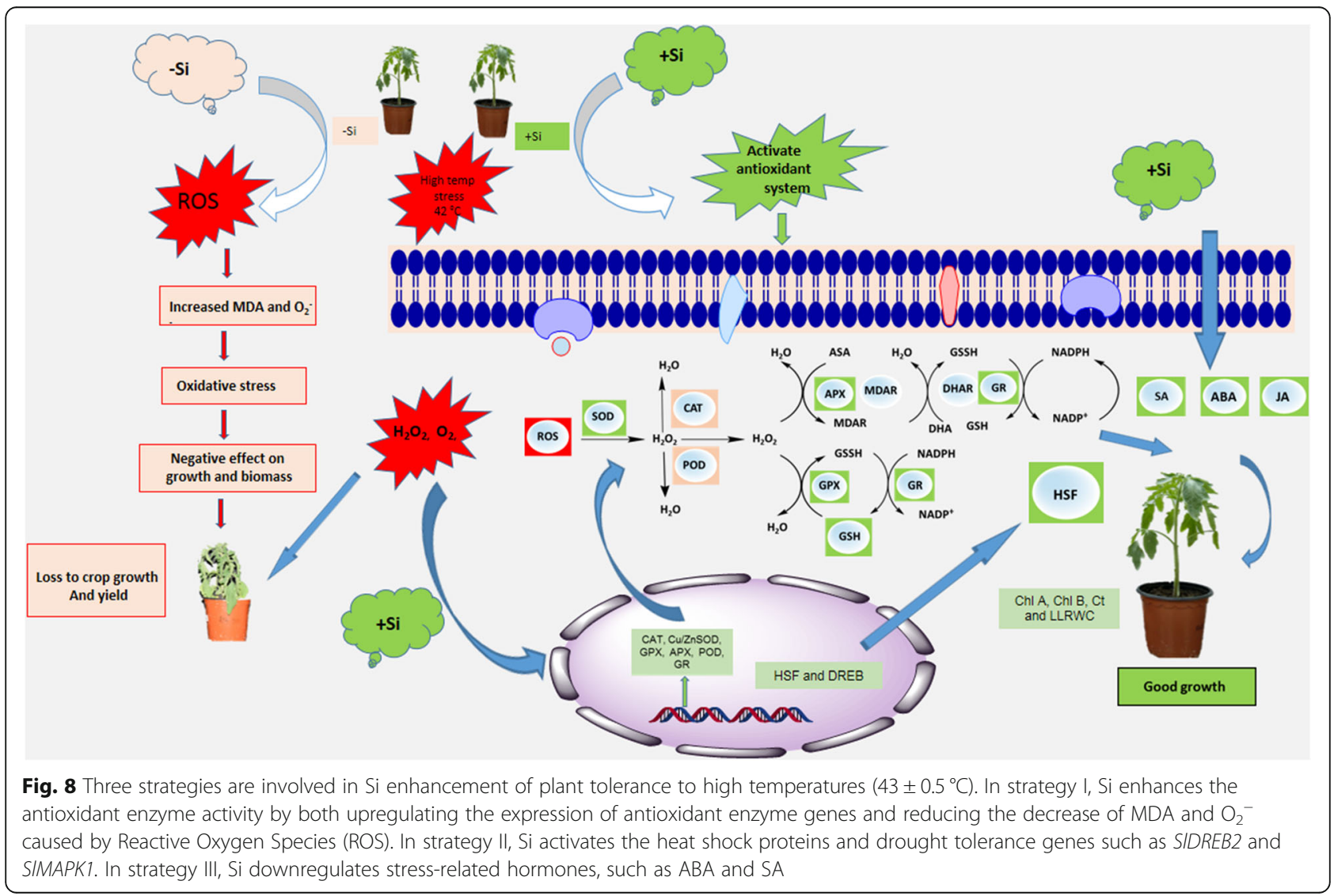


(Luan et al., 2009). Give that we used sodium silicate as a Si source in this study, both $\mathrm{Si}$ and $\mathrm{Na}^{+}$were analyzed. We did not observe any difference in the $\mathrm{Na}^{+}$concentration in plants treated with and without sodium silicate, suggesting that the observed toxicity was not due to $\mathrm{Na}^{+}$ concentration but to high temperatures and induced drought stress. Si uptake was confirmed by measuring the $\mathrm{Si}$ concentration in shoots. We also validated the higher uptake of $\mathrm{Si}$ in $+\mathrm{Si}$ plants at the mRNA level.

The function of SlLsi1 and SlLsi2 genes in Si transport and stress conditions are poorly understood. Previously, $\mathrm{Ma}$, et al. [92] described the role of Oryza sativa OsLsi1 and OsLsi2, present in the plasma membrane of rice plant cells, in Si influx and efflux. OsLsi1 is located on the distal side of the cell while OsLsi2 is located on its proximal side [92]. Our results revealed that both SlLsi1 and SlLsi2 genes were upregulated by 2- and 5 -fold and by 1.9- and 2.4-fold in $+\mathrm{Si}$ plants under normal and heat stress conditions, respectively. They were also upregulated under heat stress in -Si plants, suggesting they improved $\mathrm{Si}$ uptake and played a role in heat stress tolerance (Fig. 8). This role might be attributed to the accumulation of $\mathrm{Si}$ in the shoots, providing additional strength to the leaf and stem structure to minimize the adverse effects of heat and drought stress, hence leading to higher tolerance. The role of OsLsi1 and OsLsi2 in heavy metal tolerance was previously reported by Kim, et al. [93].

$H s f$, a regulatory protein, plays a central regulatory role in the conversion of heat stress signal perception to the expression of genes involved in the plant's stress response by interacting with promoters at the cis binding region of HSPs [94]. These in turn activate a cascade of heat stress-responsive genes that work together to improve the plant's heat stress tolerance. The regulatory role of $H s f s$ has been studied in Arabidopsis during heat stress conditions and in other crops [95, 96]. Hsfs are conserved in different species, but discrepancies regarding the function of individual $H s f s$ in HSR have also been reported. HsfAla is a master regulator for the initiation of HSR in tomato plants, but in Arabidopsis, HsfA1a, $H s f A 1 b$, and HsfAld are responsible for $\operatorname{HSR}[97,98]$. Furthemore, under heat stress, $H s f B 1$ in tomato shows both coactivator and repressor functions, while the same gene in Arabidopsis acts as a transcriptional repressor [99]. HsfA1a, HsfA2, and HsfB1 are considered essential for the activation of HSR in tomato plants under heat stress conditions [100] HsfAla and HsfB1 are produced continuously in the cell, while $H s f A 2$ is expressed under normal conditions. It was found that the expression of HsfA2 mRNA and protein increased under heat stress. Consequently, HsfA2 was more abundant when the plant was grown at higher temperatures [101]. In this study, we found that heat stress significantly enhanced the expression of $H s f s$, namely $S l H s f A 1 a, S l H s f A 1 b, S l H s f A 2$, $S l H s f A 3$, and SlHsfA7, which varied under normal conditions. This finding highlights the role of SlHsfA1a, SlHsfA1b, SlHsfA2, SlHsfA3, and SlHsfA7 in heat stress tolerance. Interestingly, we found a higher expression of $H s f s$ in + Si plants, leading us to the conclusion that exogenous $\mathrm{Si}$ application induced the expression of $H s f s$ and stress-response genes under heat stress. This ultimately activates HSR in tomato plants by activating Hsps, leading to the prevention of lipid peroxidation and the generation of excessive reactive radicals. $H s f s$ regulate the transcription changes needed to protect plants from heat stress [8]. Similarly, we found that heat increased the expression of SIDREB2 and SlMAPK1. Wang, et al. [102] previously reported that overexpression of SIMAPK1 enhanced drought and heat stress tolerance in tomato plants. Moreover, the role of MAPK1 in abiotic stresses such as cold, salinity, UV radiation, and wounding has also been reported in Arabidopsis [103, 104].

Stress-related endogenous hormonal regulation and its related pathways (such as $\mathrm{ABA}$ and $\mathrm{SA}$ ) are considered essential in mediating plant growth and physiological response under stress conditions. ABA signaling and ABA-responsive genes have been extensively studied under a wide range of stress conditions. ABA synthesis triggers $\mathrm{ABA}$-inducible gene expression and causes stomatal closure, thereby reducing water loss via transpiration and eventually restricting cellular growth [105-107]. In this study, significantly higher amounts of ABA were observed in heat-stressed -Si plants compared to $+\mathrm{Si}$ plants. This difference indicates that tomato plants experienced high levels of stress. In $+\mathrm{Si}$ plants, ABA concentration significantly decreased during heat stress and under normal conditions. These results concur with those Kim, et al. [93], who reported that ABA increased significantly when rice plants were treated with $\mathrm{Cu}, \mathrm{Cd}$, and a combination of $\mathrm{Cd}$ and $\mathrm{Cu}$ in the presence of $\mathrm{Si}$. It has been demonstrated in Pisum sativum by Li, et al. [12] that the ABA level increased upon exposure to heat stress, confirming its role in heat stress tolerance. Later, the same group reported that the ABAdeficient mutant tomato genotype is sensitive to heat stress $\left(42{ }^{\circ} \mathrm{C}\right.$ for $\left.24 \mathrm{~h}\right)[108,109]$. In this study, a significant reduction in ABA was recorded in + Si plants, an indication that $+\mathrm{Si}$ plants are less sensitive to heat stress than $-\mathrm{Si}$ plants. This was further validated by the gene expression profile, indicating that heat stress upregulated the expression of genes responsible for ABA biosynthesis. We observed higher expression of the NCED1 gene during heat stress and under normal conditions in - Si plants compared to + Si plants, suggesting that $\mathrm{Si}$ application reduced the biosynthesis of ABA.

SA is also a naturally-occurring plant hormone involved in the response to abiotic and biotic stresses and 
in the regulation of pathogenesis-associated protein expression [110]. The SA response under biotic stress has been widely reported [111]. SA also plays an important role in plant growth, ripening, and development [112] and its role in thermotolerance is well-established. Davies [112] and Li, et al. [113] reported that SA-mediated pathways could increase heat stress tolerance in plant species such as mustard, tobacco, bean, potato, tomato, and Arabidopsis thaliana. Similarly, we found that heat stress significantly improved the biosynthesis of SA in our tomato seedlings, suggesting its role in regulating heat stress tolerance. However, the results revealed that exogenous $\mathrm{Si}$ application significantly reduced SA concentration. This may be because the plants experienced less stress due to the accumulation of $\mathrm{Si}$ in the shoots, forming a protective layer on the leaves. Another possible reason is the interaction with antioxidant systems in the presence of exogenous $\mathrm{Si}$. Li, et al. [113] indicated that high levels of SA caused oxidative stress, while lower levels of SA improved the antioxidative capacity of plants and stimulated the synthesis of protective compounds, leading to enhanced tolerance to abiotic stress. Our results also concur with those of Kim, et al. [93], who reported that exogenous $\mathrm{Si}$ application significantly reduced SA biosynthesis in rice plants under heavy metal stress. Under both normal and stress conditions, the synthesis of SA is mediated by two pathways: the phenylalanine ammonia-lyase (PAL) pathway and the isochorismate (IC) pathway. The IC pathway is the major pathway in Solanum lycopersicum and Nicotiana benthamiana [114]. We found similar results at the mRNA level; SA biosynthesis-related genes (SlR1b1, SlPR-P2, SIICS, and SIPAL) were downregulated in $+\mathrm{Si}$ plants, but upregulated under heat stress in $-\mathrm{Si}$ plants. However, more comprehensive investigations are required to describe the detailed molecular mechanisms underlying the complex roles of SA in abiotic stress tolerance.

\section{Conclusion}

This study showed that Si application to tomato seedlings increased the resilience and function of tomato plants under heat stress and induced stress tolerance by modulating oxidative stress, HSP, and endogenous phytohormones, as well as the related mRNA gene expression patterns. Si application reduced the heat-mediated oxidative stress through stimulation of the antioxidant defense mechanism and increased the concentration of photosynthetic pigments in the plant. Thus, using Si for broader field applications with the advent of current changes in global climatic conditions can be an ecofriendly approach to maintain crop growth and productivity.

\section{Supplementary information}

Supplementary information accompanies this paper at https://doi.org/10. 1186/s12870-020-02456-7.

Additional file 1: Figure S1. Effects of $1 \mathrm{mM} \mathrm{Si}$ application on growth parameters of tomato plants grown under normal and heat stress conditions. (A) shoot fresh weight (B) root fresh weight.

\section{Abbreviations \\ PAL: Phenylalanine ammonia-lyase; MAPKs: Mitogen-activated protein kinases; MDA: Malondialdehyde; HSP: Heat shock proteins; SA: Salicylic acid; ABA: Abscisic acids; ROS: Reactive oxygen species; POD: Peroxidase; CAT: Catalase; SOD: Superoxide dismutase; PPO: Polyphenol peroxidase}

\section{Acknowledgments}

The authors acknowledge the support of Ms. Saffia Al Amri and Amna Al Buriaki for assisting in harvesting and treatment of plants.

\section{Authors' contributions}

AK, ALK, MN: Designed, planned and wrote the manuscript; MI, YHK, IJL: Performed endogenous phytohormonal analysis; SA, SB: Statistical analysis and graphical representation; ALK, AAH, AAR: Supervised and arranged funding. All authors have read and approved the manuscript.

\section{Funding}

The author acknowledges the financial support of University of Nizwa, Internal Funding Program to the corresponding author.

Availability of data and materials

All the data is available within the manuscript.

Ethics approval and consent to participate

No permissions were required to collect plant samples.

Consent for publication

Not applicable.

Competing interests

The authors declare that they have no competing interests.

\section{Author details}

${ }^{1}$ Natural \& Medical Sciences Research Center, University of Nizwa, Nizwa 616, Oman. ${ }^{2}$ School of Applied Biosciences, Kyungpook National University,

Daegu 41566, South Korea.

Received: 7 September 2019 Accepted: 21 May 2020

Published online: 03 June 2020

References

1. Cooke J, Leishman MR. Consistent alleviation of abiotic stress with silicon addition: a meta-analysis. Funct Ecol. 2016;30(8):1340-57.

2. Zandalinas SI, Mittler R, Balfagón D, Arbona V, Gómez-Cadenas A. Plant adaptations to the combination of drought and high temperatures. Physiol Plant. 2018;162(1):2-12

3. Tayade R, Nguyen T, Oh SA, Hwang YS, Yoon IS, Deshmuk R, Jung K-H, Park SK. Effective strategies for enhancing tolerance to high-temperature stress in Rice during the reproductive and ripening stages. Plant Breed Biotechnol. 2018;6(1):1-18.

4. Mittler R, Blumwald E. Genetic engineering for modern agriculture: challenges and perspectives. Annu Rev Plant Biol. 2010;61:443-62.

5. Hasanuzzaman M, Nahar K, Alam M, Roychowdhury R, Fujita M. Physiological, biochemical, and molecular mechanisms of heat stress tolerance in plants. Int J Mol Sci. 2013;14(5):9643-84.

6. Ashraf M, Harris P. Abiotic Stresses. Boca Raton: CRC Press; 2005. https://doi. org/10.1201/9781482293609.

7. Baxter A, Mittler R, Suzuki N. ROS as key players in plant stress signalling. J Exp Bot. 2013;65(5):1229-40.

8. Fragkostefanakis $S$, Mesihovic A, Simm S, Paupière MJ, Hu Y, Paul P, Mishra SK, Tschiersch B, Theres K, Bovy A. HsfA2 controls the activity of 
developmentally and stress-regulated heat stress protection mechanisms in tomato male reproductive tissues. Plant Physiol. 2016;170(4):2461-77.

9. Maestri E, Klueva N, Perrotta C, Gulli M, Nguyen HT, Marmiroli N. Molecular genetics of heat tolerance and heat shock proteins in cereals. Plant Mol Biol. 2002;48(5-6):667-81.

10. Wasternack C, Stenzel I, Hause B, Hause G, Kutter C, Maucher H, Neumerke J, Feussner I, Miersch O. The wound response in tomato-role of jasmonic acid. J Plant Physiol. 2006;163(3):297-306.

11. Zarate SI, Kempema LA, Walling LL. Silverleaf whitefly induces salicylic acid defenses and suppresses effectual jasmonic acid defenses. Plant Physiol. 2007;143(2):866-75.

12. Li X, Ahammed G, Zhang Y, Zhang G, Sun Z, Zhou J, Zhou Y, Xia X, Yu J, Shi K. Carbon dioxide enrichment alleviates heat stress by improving cellular redox homeostasis through an $\mathrm{ABA}$-independent process in tomato plants. Plant Biol. 2015;17(1):81-9.

13. Marschner H. Marschner, Mineral Nutrition of Higher Plants. London: Academic; 1995. p. 889. (ISBN 0-12-473543-6). Price: 29.95 Pound Sterling. In: Urban \& Fischer; 1996.

14. Yamaji N, Ma JF. Spatial distribution and temporal variation of the Rice silicon transporter Lsi1. Plant Physiol. 2007;143(3):1306-13.

15. Kim $\mathrm{Y}-\mathrm{H}$, Khan AL, Lee I-J. Silicon: a duo synergy for regulating crop growth and hormonal signaling under abiotic stress conditions. Crit Rev Biotechnol. 2016;36(6):1099-109.

16. Epstein E. Silicon. Annu Rev Plant Biol. 1999;50(1):641-64.

17. Ma JF, Takahashi E. Chapter 3 - Silicon in soil. In: Ma JF, Takahashi E, Editors. Soil, Fertilizer, and Plant Silicon Research in Japan. Amsterdam: Elsevier Science; 2002. p. 27-48. https://doi.org/10.1016/B978-044451166-9/50003-8.

18. Ma JF, Yamaji N. Silicon uptake and accumulation in higher plants. Trends Plant Sci. 2006;11(8):392-7.

19. Zhu Y, Gong H. Beneficial effects of silicon on salt and drought tolerance in plants. Agron Sustain Dev. 2014;34(2):455-72.

20. Rizwan M, Ali S, Ibrahim M, Farid M, Adrees M, Bharwana SA, Zia-ur-Rehman M, Qayyum MF, Abbas F. Mechanisms of silicon-mediated alleviation of drought and salt stress in plants: a review. Environ Sci Pollut Res. 2015; 22(20):15416-31.

21. Ma JF. Role of silicon in enhancing the resistance of plants to biotic and abiotic stresses. Soil Sci Plant Nutr. 2004;50(1):11-8.

22. Marafon AC, Endres L. Silicon: fertilization and nutrition in higher plants. In: Embrapa Tabuleiros Costeiros-Artigo em periódico indexado (ALICE); 2013.

23. Shen $X$, Xiao $X$, Dong Z, Chen $Y$. Silicon effects on antioxidative enzymes and lipid peroxidation in leaves and roots of peanut under aluminum stress. Acta Physiol Plant. 2014;36(11):3063-9.

24. Pontigo S, Ribera A, Gianfreda L, de la Luz MM, Nikolic M, Cartes P. Silicon in vascular plants: uptake, transport and its influence on mineral stress under acidic conditions. Planta. 2015;242(1):23-37.

25. Galvez L, Clark RB. Effects of silicon on growth and mineral composition of sorghum (Sorghum bicolor) grown with toxic levels of aluminium. In: Wright RJ, Baligar VC, Murrmann RP, Editors. Plant-Soil Interactions at Low pH. Developments in Plant and Soil Sciences. vol 45. Dordrecht: Springer; 1991. https://doi.org/10.1007/978-94-011-3438-5_92.

26. Pontigo S, Godoy K, Jiménez H, Gutiérrez-Moraga A, Mora MD, Cartes P. Siliconmediated alleviation of aluminum toxicity by modulation of AL/SI uptake and antioxidant performance in ryegrass plants. Front Plant Sci. 2017;8:642.

27. Van Bockhaven J, De Vleesschauwer D, Höfte M. Towards establishing broad-spectrum disease resistance in plants: silicon leads the way. J Exp Bot. 2012;64(5):1281-93.

28. Cotterill JV, Watkins RW, Brennon CB, Cowan DP. Boosting silica levels in wheat leaves reduces grazing by rabbits. Pest Manag Sci. 2007;63(3):247-53.

29. Kidd P, Llugany M, Poschenrieder C, Gunse B, Barcelo J. The role of root exudates in aluminium resistance and silicon-induced amelioration of aluminium toxicity in three varieties of maize (Zea mays L.). J Exp Bot. 2001; 52(359):1339-52.

30. Al-aghabary K, Zhu Z, Shi Q. Influence of silicon supply on chlorophyll content, chlorophyll fluorescence, and antioxidative enzyme activities in tomato plants under salt stress. J Plant Nutr. 2005;27(12):2101-15.

31. Shahnaz G, Shekoofeh E, Kourosh D, Moohamadbagher B. Interactive effects of silicon and aluminum on the malondialdehyde (MDA), proline, protein and phenolic compounds in Borago officinalis L. J Med Plants Res. 2011; 5(24):5818-27.

32. Tripathi D, Bashri G, Shweta S, Ahmad P, Singh V. Efficacy of silicon against aluminum toxicity in plants: an overview. Silicon Plants. 2017;1:355-66.
33. Kim Y-H, Khan AL, Waqas M, Lee I-J. Silicon regulates antioxidant activities of crop plants under abiotic-induced oxidative stress: a review. Front Plant Sci. 2017:8:510.

34. Sumanta N, Haque Cl, Nishika J, Suprakash R. Spectrophotometric analysis of chlorophylls and carotenoids from commonly grown fern species by using various extracting solvents. Res J Chem Sci. 2014;2231:606X.

35. Cao Y-Y, Yang M-T, Chen S-Y, Zhou Z-Q, Li X, Wang X-J, Bai J-G. Exogenous sucrose influences antioxidant enzyme activities and reduces lipid peroxidation in water-stressed cucumber leaves. Biol Plant. 2015; 59(1):147-53.

36. Bilal S, Shahzad R, Khan AL, Kang SM, Imran QM, Al-Harrasi A, Yun BW, Lee IJ. Endophytic microbial consortia of phytohormones-producing fungus Paecilomyces formosus LHL10 and bacteria Sphingomonas sp. LK11 to Glycine max L. regulates physio-hormonal changes to attenuate aluminum and zinc stresses. Frontiers Plant Sci. 2018;9:1273.

37. Liu L, Han R, Yu N, Zhang W, Xing L, Xie D, Peng D. A method for extracting high-quality total RNA from plant rich in polysaccharides and polyphenols using Dendrobium huoshanense. PLoS One. 2018;13(5):e0196592.

38. Schmittgen TD, Livak KJ. Analyzing real-time PCR data by the comparative $C$ T method. Nat Protoc. 2008;3(6):1101.

39. Ohkawa H, Ohishi N, Yagi K. Assay for lipid peroxides in animal tissues by thiobarbituric acid reaction. Anal Biochem. 1979;95(2):351-8.

40. Gajewska E, Skłodowska M. Differential biochemical responses of wheat shoots and roots to nickel stress: antioxidative reactions and proline accumulation. Plant Growth Regul. 2008:54(2):179-88.

41. Bradford MM. A rapid and sensitive method for the quantitation of microgram quantities of protein utilizing the principle of protein-dye binding. Anal Biochem. 1976;72(1-2):248-54.

42. Kar M, Mishra D. Catalase, peroxidase, and polyphenoloxidase activities during rice leaf senescence. Plant Physiol. 1976;57(2):315-9.

43. Aebi H. Catalase in vitro. In: Methods in enzymology, vol. 105. Academic Press; 1984. p. 121-126. https://doi.org/10.1016/S0076-6879(84)05016-3.

44. Seskar M, Shulaev V, Raskin I. Endogenous methyl salicylate in pathogeninoculated tobacco plants. Plant Physiol. 1998;116(1):387-92.

45. Shahzad R, Waqas M, Khan AL, Asaf S, Khan MA, Kang S-M, Yun B-W, Lee I-J. Seed-borne endophytic bacillus amyloliquefaciens RWL-1 produces gibberellins and regulates endogenous phytohormones of Oryza sativa. Plant Physiol Biochem. 2016;106:236-43.

46. Shahzad R, Khan AL, Waqas M, Ullah I, Bilal S, Kim Y-H, Asaf S, Kang S-M, Lee I-J. Metabolic and proteomic alteration in phytohormone-producing endophytic bacillus amyloliquefaciens RWL-1 during methanol utilization. Metabolomics. 2019;15(2):16

47. Jain M, Mathur G, Koul S, Sarin N. Ameliorative effects of proline on salt stress-induced lipid peroxidation in cell lines of groundnut (Arachis hypogaea L.). Plant Cell Rep. 2001;20(5):463-8.

48. Schieber M, Chandel NS. ROS function in redox signaling and oxidative stress. Curr Biol. 2014;24(10):R453-62.

49. Ayala A, Muñoz MF, Argüelles S. Lipid Peroxidation: Production, Metabolism, and Signaling Mechanisms of Malondialdehyde and 4-Hydroxy-2-Nonenal. Oxidative Medicine and Cellular Longevity. 2014;2014:360438. https://doi. org/10.1155/2014/360438.

50. Chaves M, Oliveira M. Mechanisms underlying plant resilience to water deficits: prospects for water-saving agriculture. J Exp Bot. 2004;55(407): 2365-84.

51. Agarwal PK, Agarwal P, Reddy M, Sopory SK. Role of DREB transcription factors in abiotic and biotic stress tolerance in plants. Plant Cell Rep. 2006; 25(12):1263-74

52. Shinozaki K, Yamaguchi-Shinozaki K, Seki M. Regulatory network of gene expression in the drought and cold stress responses. Curr Opin Plant Biol. 2003;6(5):410-7.

53. Bartels D, Sunkar R. Drought and salt tolerance in plants. Crit Rev Plant Sci. 2005;24(1):23-58.

54. Du X, Zhao X, Li X, Guo C, Lu W, Gu J, Xiao K. Overexpression of TaSRK2C1, a wheat SNF1-related protein kinase 2 gene, increases tolerance to dehydration, salt, and low temperature in transgenic tobacco. Plant Mol Biol Report. 2013;31(4):810-21.

55. Xia X-J, Zhou Y-H, Shi K, Zhou J, Foyer CH, Yu J-Q. Interplay between reactive oxygen species and hormones in the control of plant development and stress tolerance. J Exp Bot. 2015;66(10):2839-56.

56. Dobrá J, Černý M, Štorchová H, Dobrev P, Skalák J, Jedelský PL, Lukšanová H, Gaudinová A, Pešek B, Malbeck J. The impact of heat 
stress targeting on the hormonal and transcriptomic response in Arabidopsis. Plant Sci. 2015;231:52-61.

57. Zhou R, Yu X, Ottosen C-O, Rosenqvist E, Zhao L, Wang Y, Yu W, Zhao T, Wu Z. Drought stress had a predominant effect over heat stress on three tomato cultivars subjected to combined stress. BMC Plant Biol. 2017;17(1):24.

58. Chen J, Xu W, Velten J, Xin Z, Stout J. Characterization of maize inbred lines for drought and heat tolerance. J Soil Water Conserv. 2012;67(5):354-64.

59. Mishra KB, lannacone R, Petrozza A, Mishra A, Armentano N, La Vecchia G, Trtílek M, Cellini F, Nedbal L. Engineered drought tolerance in tomato plants is reflected in chlorophyll fluorescence emission. Plant Sci. 2012;182:79-86.

60. Patanè C. Leaf area index, leaf transpiration and stomatal conductance as affected by soil water deficit and VPD in processing tomato in semi arid Mediterranean climate. J Agron Crop Sci. 2011;197(3):165-76.

61. Abdelmageed A, Gruda N, Geyer B. Effect of high temperature and heat shock on tomato (Lycopersicon esculentum Mill) genotypes under controlled conditions. Göttingen, 8-10 October 2003: Deutscher Tropentag 2003; 2003.

62. Camejo D, Rodríguez P, Morales MA, Dell'Amico JM, Torrecillas A, Alarcón JJ. High temperature effects on photosynthetic activity of two tomato cultivars with different heat susceptibility. J Plant Physiol. 2005;162(3):281-9.

63. Camejo D, Jiménez A, Alarcón JJ, Torres W, Gómez JM, Sevilla F. Changes in photosynthetic parameters and antioxidant activities following heat-shock treatment in tomato plants. Funct Plant Biol. 2006;33(2):177-87.

64. Liu J-J, Lin S-H, Xu P-L, Wang X-J, Bai J-G. Effects of exogenous silicon on the activities of antioxidant enzymes and lipid peroxidation in chillingstressed cucumber leaves. Agric Sci China. 2009;8(9):1075-86.

65. Sivanesan I, Son M, Soundararajan P, Jeong B. Effect of silicon on growth and temperature stress tolerance of Nephrolepis exaltata'Corditas'. Korean J Horticult Sci Technol. 2014;32(2):142-8.

66. Agarie S, Hanaoka N, Ueno O, Miyazaki A, Kubota F, Agata W, Kaufman PB. Effects of silicon on tolerance to water deficit and heat stress in rice plants (Oryza sativa L.), monitored by electrolyte leakage. Plant Prod Sci. 1998;1(2):96-103.

67. Mahdieh M, Habibollahi N, Amirjani M, Abnosi M, Ghorbanpour M. Exogenous silicon nutrition ameliorates salt-induced stress by improving growth and efficiency of PSII in Oryza sativa L. cultivars. J Soil Sci Plant Nutr. 2015;15(4):1050-60.

68. Abbas T, Sattar A, ljaz M, Aatif M, Khalid S, Sher A. Exogenous silicon application alleviates salt stress in okra. Hortic Environ Biotechnol. 2017;58(4):342-9.

69. Chen D, Chen D, Xue R, Long J, Lin X, Lin Y, Jia L, Zeng R, Song Y. Effects of boron, silicon and their interactions on cadmium accumulation and toxicity in rice plants. J Hazard Mater. 2019;367:447-55.

70. Naz N, Durrani F, Shah Z, Khan N, Ullah I. Influence of heat stress on growth and physiological activities of potato (Solanum tuberosum L.). Phyton Int J Exp Botany. 2018;87:225-30.

71. Wang L-J, Fan L, Loescher W, Duan W, Liu G-J, Cheng J-S, Luo H-B, Li S-H. Salicylic acid alleviates decreases in photosynthesis under heat stress and accelerates recovery in grapevine leaves. BMC Plant Biol. 2010;10(1):34

72. Chalanika De Silva HC. Asaeda T: effects of heat stress on growth, photosynthetic pigments, oxidative damage and competitive capacity of three submerged macrophytes. J Plant Interact. 2017;12(1):228-36.

73. Li X, Wei J-P, Scott E, Liu J-W, Guo S, Li Y, Zhang L, Han W-Y. Exogenous melatonin alleviates cold stress by promoting antioxidant defense and redox homeostasis in Camellia sinensis L. Molecules. 2018;23(1):165.

74. Muneer S, Park YG, Kim S, Jeong BR. Foliar or subirrigation silicon supply mitigates high temperature stress in strawberry by maintaining photosynthetic and stress-responsive proteins. J Plant Growth Regul. 2017;36(4):836-45

75. Wang S, Liu P, Chen D, Yin L, Li H, Deng X. Silicon enhanced salt tolerance by improving the root water uptake and decreasing the ion toxicity in cucumber. Front Plant Sci. 2015:6:759.

76. Shi Y, Zhang Y, Han W, Feng R, Hu Y, Guo J, Gong H. Silicon enhances water stress tolerance by improving root hydraulic conductance in Solanum lycopersicum L. Front Plant Sci. 2016;7:196.

77. Ali N, Schwarzenberg A, Yvin J-C, Hosseini SA. Regulatory role of silicon in mediating differential stress tolerance responses in two contrasting tomato genotypes under osmotic stress. Front Plant Sci. 2018;9:1475.

78. Merewitz EB, Liu S. Improvement in heat tolerance of creeping Bentgrass with melatonin, Rutin, and silicon. J Am Soc Hortic Sci. 2019;144(2):141-8.

79. Hussain I, Parveen A, Rasheed R, Ashraf MA, Ibrahim M, Riaz S, Afzaal Z, lqbal M. Exogenous Silicon Modulates Growth, Physio-Chemicals and Antioxidants in Barley (Hordeum vulgare L.) Exposed to Different Temperature Regimes. Silicon. 2019;11:2753-62.
80. Gunes A, Pilbeam DJ, Inal A, Bagci EG, Coban S. Influence of silicon on antioxidant mechanisms and lipid peroxidation in chickpea (Cicer arietinum L.) cultivars under drought stress. J Plant Interact. 2007;2(2):105-13.

81. Huang F, Wen X-H, Cai Y-X, Cai K-Z. Silicon-mediated enhancement of heavy metal tolerance in Rice at different growth stages. Int J Environ Res Public Health. 2018;15(10):2193.

82. Sharma P, Jha AB, Dubey RS, Pessarakli M. Reactive Oxygen Species, Oxidative Damage, and Antioxidative Defense Mechanism in Plants under Stressful Conditions. Journal of Botany. 2012;2012:217037. https://doi.org/10. 1155/2012/217037.

83. Kim YH, Khan AL, Waqas M, Shim JK, Kim DH, Lee KY, Lee IJ. Silicon application to rice root zone influenced the phytohormonal and antioxidant responses under salinity stress. J Plant Growth Regul. 2014;33(2):137-49.

84. Zhang F-Q, Wang Y-S, Lou Z-P, Dong J-D. Effect of heavy metal stress on antioxidative enzymes and lipid peroxidation in leaves and roots of two mangrove plant seedlings (Kandelia candel and Bruguiera gymnorrhiza). Chemosphere. 2007;67(1):44-50.

85. Zandalinas SI, Balfagón D, Arbona V, Gómez-Cadenas A. Modulation of antioxidant defense system is associated with combined drought and heat stress tolerance in citrus. Front Plant Sci. 2017;8:953.

86. Zhu Z, Wei G, Li J, Qian Q, Yu J. Silicon alleviates salt stress and increases antioxidant enzymes activity in leaves of salt-stressed cucumber (Cucumis sativus L.). Plant Sci. 2004;167(3):527-33.

87. Soundararajan P, Manivannan A, Park YG, Muneer S, Jeong BR. Silicon alleviates salt stress by modulating antioxidant enzyme activities in Dianthus caryophyllus 'Tula'. Hortic Environ Biotechnol. 2015;56(2):233-9.

88. Sahebi M, Hanafi MM, Rafii MY, Azizi P, Abiri R, Kalhori N, Atabaki N. Screening and Expression of a Silicon Transporter Gene (Lsi1) in Wild-Type Indica Rice Cultivars. BioMed Research International. 2017;2017:9064129. https://doi.org/10.1155/2017/9064129.

89. Alberto CM, Fontão de Lima Filho O, Manuel JC, Gabriela SK, Lia MM, Mui ST. Assessment of the effect of silicon on antioxidant enzymes in cotton plants by multivariate analysis. J Agric Food Chem. 2013;61 (47):11243-9.

90. Ma D, Sun D, Wang C, Qin H, Ding H, Li Y, Guo T. Silicon application alleviates drought stress in wheat through transcriptional regulation of multiple antioxidant defense pathways. J Plant Growth Regul. 2016:35(1):1-10.

91. Luan S, Lan W, Lee SC. Potassium nutrition, sodium toxicity, and calcium signaling: connections through the CBL-CIPK network. Curr Opin Plant Biol. 2009;12(3):339-46

92. Ma JF, Yamaji N, Mitani N, Tamai K, Konishi S, Fujiwara T, Katsuhara M, Yano M. An efflux transporter of silicon in rice. Nature. 2007; 448(7150):209.

93. Kim $Y-H$, Khan AL, Kim D-H, Lee S-Y, Kim K-M, Waqas M, Jung H-Y, Shin J-H, Kim J-G, Lee I-J. Silicon mitigates heavy metal stress by regulating P-type heavy metal ATPases, Oryza sativa low silicon genes, and endogenous phytohormones. BMC Plant Biol. 2014;14(1):13.

94. Guo M, Liu J-H, Ma X, Luo D-X, Gong Z-H, Lu M-H. The plant heat stress transcription factors (HSFs): structure, regulation, and function in response to abiotic stresses. Front Plant Sci. 2016;7:114.

95. Fragkostefanakis S, Roeth S, Schleiff E, SCHARF KD. Prospects of engineering thermotolerance in crops through modulation of heat stress transcription factor and heat shock protein networks. Plant Cell Environ. 2015;38(9):1881-95.

96. Scharf K-D, Berberich T, Ebersberger I, Nover L. The plant heat stress transcription factor ( $\mathrm{Hsf}$ ) family: structure, function and evolution. Biochimica et Biophysica Acta. 2012;1819(2):104-19.

97. Liu HC, Liao HT, Charng YY. The role of class A1 heat shock factors (HSFA1s) in response to heat and other stresses in Arabidopsis. Plant Cell Environ. 2011;34(5):738-51.

98. Yoshida T, Ohama N, Nakajima J, Kidokoro S, Mizoi J, Nakashima K, Maruyama K, Kim J-M, Seki M, Todaka D. Arabidopsis HsfA1 transcription factors function as the main positive regulators in heat shock-responsive gene expression. Mol Gen Genomics. 2011;286(5-6):321-32.

99. Bharti K, von Koskull-Döring P, Bharti S, Kumar P, Tintschl-Körbitzer A, Treuter $E$, Nover L. Tomato heat stress transcription factor HsfB1 represents a novel type of general transcription coactivator with a histone-like motif interacting with the plant CREB binding protein ortholog HAC1. Plant Cell. 2004;16(6):1521-35.

100. Hahn A, Bublak D, Schleiff E, Scharf K-D. Crosstalk between Hsp90 and Hsp70 chaperones and heat stress transcription factors in tomato. Plant Cell. 2011;23(2):741-55 
101. Scharf K-D, Heider H, Höhfeld I, Lyck R, Schmidt E, Nover L. The tomato Hsf system: HsfA2 needs interaction with HsfA1 for efficient nuclear import and may be localized in cytoplasmic heat stress granules. Mol Cell Biol. 1998; 18(4):2240-51.

102. Wang L, Zhao R, Li R, Yu W, Yang M, Sheng J, Shen L. Enhanced drought tolerance in tomato plants by overexpression of SIMAPK1. Plant Cell Tissue Org Cult. 2018;133(1):27-38.

103. Colcombet J, Hirt H. Arabidopsis MAPKs: a complex signalling network involved in multiple biological processes. Biochem J. 2008;413(2):217-26.

104. Mishra NS, Tuteja R, Tuteja N. Signaling through MAP kinase networks in plants. Arch Biochem Biophys. 2006;452(1):55-68.

105. Acharya BR, Assmann SM. Hormone interactions in stomatal function. Plant Mol Biol. 2009;69(4):451-62.

106. Yoshida T, Obata T, Feil R, Lunn JE, Fujita Y, Yamaguchi-Shinozaki K, Fernie AR. The role of Abscisic acid signaling in maintaining the metabolic balance required for Arabidopsis growth under nonstress conditions. Plant Cell. 2019:31(1):84-105.

107. Sah SK, Reddy KR, Li J. Abscisic acid and abiotic stress tolerance in crop plants. Front Plant Sci. 2016;7:571.

108. Larkindale J, Knight MR. Protection against heat stress-induced oxidative damage in Arabidopsis involves calcium, abscisic acid, ethylene, and salicylic acid. Plant Physiol. 2002;128(2):682-95.

109. Larkindale J, Hall JD, Knight MR, Vierling E. Heat stress phenotypes of Arabidopsis mutants implicate multiple signaling pathways in the acquisition of thermotolerance. Plant Physiol. 2005;138(2):882-97.

110. Hara M, Furukawa J, Sato A, Mizoguchi T, Miura K. Abiotic Stress and Role of Salicylic Acid in Plants. In: Ahmad P, Prasad MNV, Editors. Abiotic Stress Responses in Plants: Metabolism, Productivity and Sustainability. New York: Springer; 2012.

111. Vlot AC, Dempsey DMA, Klessig DF. Salicylic acid, a multifaceted hormone to combat disease. Annu Rev Phytopathol. 2009;47:177-206.

112. Davies PJ. Plant Hormones Physiology, Biochemistry and Molecular Biology. Dordrecht: Kluwer Academic; 1995. p 1-12.

113. Li S, Zhou X, Chen L, Huang W, Yu D. Functional characterization of Arabidopsis thaliana WRKY39 in heat stress. Mol Cells. 2010;29(5):475-83.

114. Dempsey DM, Vlot AC, Wildermuth MC, Klessig DF. Salicylic acid biosynthesis and metabolism. In: The Arabidopsis book/American Society of Plant Biologists, vol. 9; 2011.

\section{Publisher's Note}

Springer Nature remains neutral with regard to jurisdictional claims in published maps and institutional affiliations.

\section{Ready to submit your research? Choose BMC and benefit from}

- fast, convenient online submission

- thorough peer review by experienced researchers in your field

- rapid publication on acceptance

- support for research data, including large and complex data types

- gold Open Access which fosters wider collaboration and increased citations

- maximum visibility for your research: over $100 \mathrm{M}$ website views per year

At $\mathrm{BMC}$, research is always in progress.

Learn more biomedcentral.com/submissions 